Efeito do bloqueio meiótico na expressão, atividade e distribuição do fator promotor da meiose (MPF) e da proteína cinase ativada por mitógenos (MAPK) em oócitos bovinos 


\section{Efeito do bloqueio meiótico na expressão, atividade e distribuição do Fator Promotor da Meiose (MPF) e da Proteína Cinase Ativada por Mitógenos (MAPK) em oócitos bovinos}

Tese de Doutorado apresentado à Comissão de Pós-Graduação da Faculdade de Zootecnia e Engenharia de Alimentos da Universidade de São Paulo, como parte dos requisitos para obtenção do Título de Doutor em Zootecnia.

Área de concentração: Qualidade e Produtividade Animal.

Orientadora: Profa. Dra. Cláudia Lima Verde Leal 


\section{FICHA CATALOGRÁFICA}

preparada pela

Biblioteca da Faculdade de Zootecnia e Engenharia de Alimentos da Universidade de São Paulo

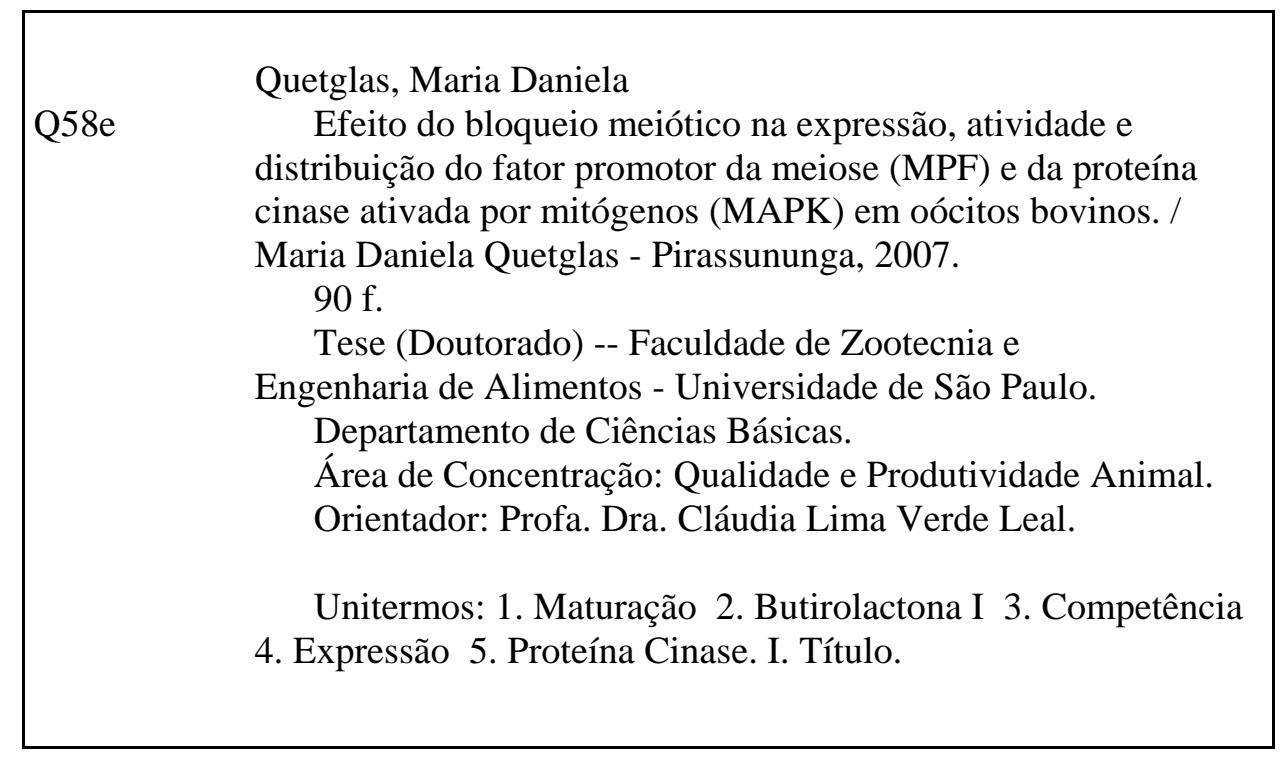


A todos os que ajudaram direta ou indiretamente a realizar esta tese 


\section{RESUMO}

QUETGLAS, M.D. Efeito do bloqueio meiótico na expressão, atividade e distribuição do fator promotor da meiose (MPF) e da proteína cinase ativada por mitógenos (MAPK) em oócitos bovinos. 90 f. 2007. Tese (Doutorado) - Faculdade de Zootecnia e Engenharia de Alimentos, Universidade de São Paulo, Pirassununga 2007.

Apesar dos grandes avanços na produção in vitro (PIV) de embriões bovinos, a produção de blastocistos se mantém ainda aquém do observado in vivo, indicando que melhorais ainda são necessárias no processo de PIV. A competência para o desenvolvimento de oócitos tem sido relacionada, entre outros fatores, à interrupção do período de capacitação. Foi sugerido que o bloqueio meiótico poderia permitir ao oócito um tempo adicional para adquirir a competência. Embora ainda não se tenha melhorado o desenvolvimento embrionário com esse procedimento, o bloqueio meiótico com inibidores de cinases dependentes de ciclinas (CDK), como a butirolactona I (BLI), pode ser uma ferramenta útil na compreensão do desenvolvimento do oócito. O presente trabalho teve por objetivo averiguar o efeito da inibição de CDK com $\mathrm{BLI}$, para bloquear temporariamente a retomada da meiose, sobre fatores que controlam o ciclo celular meiótico de oócitos bovinos. Oócitos bovinos obtidos de abatedouros foram bloqueados em vesícula germinativa (VG) in vitro com $10 \mu \mathrm{M}$ de BLI por 24 h (BVG - bloqueado imaturo). Parte desses oócitos foi depois maturada in vitro por mais $24 \mathrm{~h}$ (BMII - bloqueado maturado). Como controles foram utilizados oócitos recém-aspirados dos folículos (VG - controle imaturo) ou maturados in vitro sem bloqueio meiótico prévio (MII - controle maturado). Os diferentes grupos de oócitos foram avaliados quanto a: 1) expressão de RNAm dos componentes do MPF (p34 ${ }^{\mathrm{cdc} 2}$ e ciclina B1) e da MAPK; 2) expressão das proteínas do MPF (p34 cdc2 e ciclina B1) e MAPK (p44 e p42); 3) atividade das proteínas MPF e MAPK durante a maturação in vitro de oócito submetidos ou não ao bloqueio da meiose pré-maturação e 4) a localização subcelular das proteínas p34 ${ }^{\mathrm{cdc} 2}$, ciclina B1 e MAPK nos oócitos. Foi observado que: 1) a abundância relativa do RNAm de p34 ${ }^{\text {cdc2 }}$ e MAPK reduziu-se com a maturação, enquanto a ciclina B1 menteve-se estável; o 
bloqueio meiótico manteve o mesmo padrão de acordo com o estádio de maturação; 2) as proteínas de p34 ${ }^{\mathrm{cdc} 2}$ e MAPK mantiveram-se estáveis durante a maturação, enquanto a ciclina B1 não foi detectada em oócitos imaturos e o foi nos maturados; o bloqueio meiótico também manteve a expressão das proteínas de acordo com o estádio de maturação; 3) as atividades de MPF e MAPK foram pouco afetadas pelo bloqueio meiótico; 4) as proteínas foram todas detectadas no citoplasma dos oócitos imaturos (bloqueados ou não) e maturados (bloqueados ou não), sendo apenas a p34 $4^{\mathrm{cdc2}}$ também localizada no núcleo de oócitos imaturos (bloqueados ou não). Diante dos resultados conclui-se que o bloqueio da meiose mantém o mesmo padrão de expressão, atividade e localização subcelular do MPF e da MAPK em oócitos imaturos e maturados, sugerindo que a tradução das mensagens, a ativação das cinases e a distribuição das proteínas foram controladas de acordo com o estádio da meiose, não sendo afetadas pelo bloqueio.

Palavras-chave: maturação, butirolactona I, competência, expressão, proteína cinase. 


\section{ABSTRACT}

QUETGLAS, M.D. Effect of meiosis block on expression, activity and distribution of meiosis promoting factor (MPF) and mitogen-activated protein kinase (MAPK) in bovine oocytes. 90 f. 2007. Thesis (PhD) Faculdade de Zootecnia e Engenharia de Alimentos, Universidade de São Paulo, Pirassununga 2007.

Although there have been great improvements in in vitro production (IVP) of bovine embryos, blastocyst production is still beyond that observed in vivo, indicating that more improvements are necessary in the IVP system. Developmental competence of oocytes has been related to, among other factors, the interruption in oocyte capacitation. Is has been suggested that meiosis block would allow the oocyte additional time to acquire competence. Although this procedure has not been successful in increasing embryo development, meiosis block with cyclin dependent kinase (CDK) inhibitors, such as butyrolactone I (BLI) can be a useful tool to study oocyte development. The present study aimed to assess the effects CDK inhibition with BLI, to temporarily block meiosis resumption, on factors involved in meiosis cell cycle control in bovine oocytes. Oocytes, obtained form slaughterhouse ovaries, were maintained in germinal vesicle (GV) arrest in vitro with $10 \mu \mathrm{M} \mathrm{BLI}$ for $24 \mathrm{~h}$ (BVG - blocked immature). A part of these oocytes was matured in vitro for another $24 \mathrm{~h}$ (BMII - blocked and matured). As controls, oocytes were also assessed soon after follicle aspiration (GV -immature control) or matured in vitro for $24 \mathrm{~h}$ without prior meiosis block (MII - matured control). The different groups of oocytes were assessed for: 1) mRNA expression for the MPF components (p34 ${ }^{\mathrm{cdc2}}$ and cyclin B1) and MAPK; 2 ) expression of MPF (p34 ${ }^{\mathrm{cdc} 2}$ and cyclin B1) and MAPK (p44 and p42) proteins; 3) MPF and MAPK activities during maturation of oocytes submitted or not to prematuration meiosis block and 4) p34 ${ }^{\mathrm{cdc} 2}$, cyclin B1 and MAPK subcellular localization within oocytes. During the study it was observed that: 1 ) relative abundance of $\mathrm{p} 34^{\mathrm{cdc} 2}$ and MAPK mRNA was reduced after maturation, while cyclin B1 mRNA remained stable; meiosis 
block maintained the same pattern according to maturation stage; 2) p34 cdc2 and MAPK proteins remained stable after maturation while cyclin B1 protein was undetected in immature oocytes and detected in the matured ones; meiosis block also maintained the same protein expression according to maturation stage; 3) MPF and MAPK activities were little affected by meiosis block and 4) all proteins were detected in the cytoplasm of immature (blocked or not) and matured (blocked or not) oocytes, and only showed a specific nuclear localizations in immature oocytes (blocked or not). According to the results it may be concluded that meiosis block maintained the same pattern of MPF and MAPK expression, activity and subcellular localization in immature and matured oocytes, suggesting that mRNA translation, kinase activation and protein distribution were controlled according to the maturation stage and were not affected by meiosis block.

Keywords: maturation, butyrolactone I, competence, expression, protein kinase. 


\section{LISTA DE SIGLAS}

AI

AII

AMPc

ANOVA

ATP

BLI

BOH

BSA

CDK

cdk1

CDKI

CIV

DMSO

DNA

FITC

FIV

FSH

FZEA

IP

LH

MAPK

MBP

MI
Anáfase I

Anáfase II

Adenosina monofosfato cíclica

Análise de variância

Adenosina trifosfato

Butirolactona I

Bohemina

Albumina sérica bovina

Cinase dependente de ciclina

Cinase dependente de ciclina $1, \mathrm{p} 34^{\text {cdc2 }}$

Inibidor de cinase dependente de ciclina

Cultivo in vitro

Dimetilsulfóxido

Ácido desoxirribonucleico

Isotiocianato de fluoresceína

Fecundação in vitro

Hormônio folículo estimulante

Faculdade de Zootecnia e Engenharia de Alimentos

Iodeto de propídio

Hormônio luteinizante

Proteína cinase ativada por mitógeno

Proteína básica de mielina

Metáfase I 
Metáfase II

MIV Maturação in vitro

MPF Fator promotor da maturação (ou meiose ou mitose)

PBS Solução salina tamponada com fosfato

PCR Reação em cadeia de polimerase

PIV Produção in vitro

PVA Álcool polivinílico

PVP Polivilpirrolidona

QVG Quebra da vesícula germinativa

RNA Ácido ribonucleico

RNAm Ácido ribonucléico mensageiro

ROS Roscovitina

SFB Soro fetal bovino

TBS Solução salina tamponada com Tris

TCM-199 Tissue culture medium-199

TI Telófase I

TII Telófase II

VG Vesícula germinativa 


\section{LISTA DE SÍMBOLOS}

\begin{tabular}{|c|c|}
\hline $\mathrm{CO}_{2}$ & Dióxido de carbono \\
\hline $\boldsymbol{\mu C} \mathbf{i}$ & MicroCurie \\
\hline$\mu \mathrm{g}$ & Micrograma \\
\hline$\mu \mathbf{l}$ & Microlitro \\
\hline$\mu \mathrm{m}$ & Micrômetro \\
\hline $\boldsymbol{\mu M}$ & Micromolar \\
\hline g & Grama \\
\hline G & Gauge, calibre \\
\hline $\mathbf{h}$ & Hora(s) \\
\hline $\mathbf{M}$ & Molar \\
\hline MBq & megaBequerel \\
\hline mg & Miligrama \\
\hline $\min$ & Minuto(s) \\
\hline $\mathbf{m l}$ & Mililitro \\
\hline $\mathbf{m M}$ & Milimolar \\
\hline mm & Milímetros \\
\hline $\mathrm{NaCl}$ & Cloreto de sódio \\
\hline${ }^{\circ} \mathbf{C}$ & Graus Celsius (centígrados) \\
\hline $\mathbf{T B q}$ & taquiBequerel \\
\hline
\end{tabular}




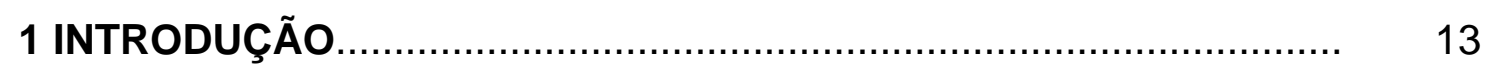

2 REVISÃO DE LITERATURA …….................................................. 15

2.1 Oogênese e foliculogênese............................................................. 15

2.1.1 Crescimento do oócito............................................................ 16

2.1.2 Capacitação do oócito............................................................... 17

2.1.3 Maturação do oócito..................................................................... 18

2.1.3.1 Maturação nuclear.................................................................... 18

2.1.3.2 Maturação citoplasmática........................................................... 19

2.2 Controle da maturação ............................................................... 20

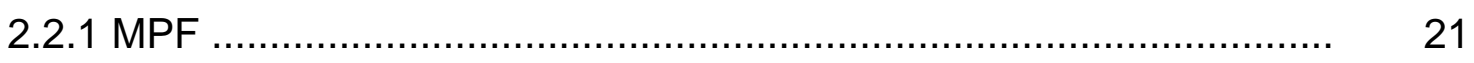

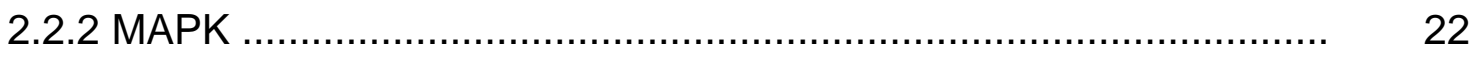

2.3Competência oocitária................................................................ 23

2.4 Bloqueio meiótico....................................................................... 25

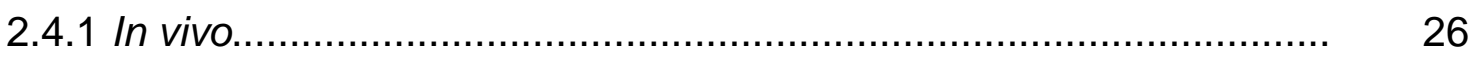

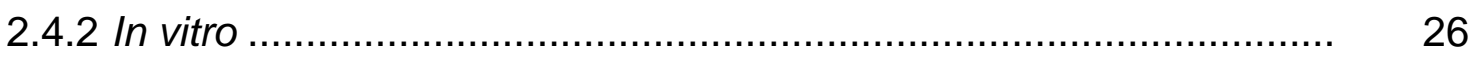

3 MATERIAL E MÉTODOS............................................................ 30

3.1 Local do Experimento...............................................................

3.2 Coleta dos ovários e seleção dos oócitos.......................................... 30

3.3 Bloqueio da meiose .................................................................. 31

3.4 Maturação in vitro dos oócitos........................................................ 31

3.5 PCR em tempo real................................................................. 32

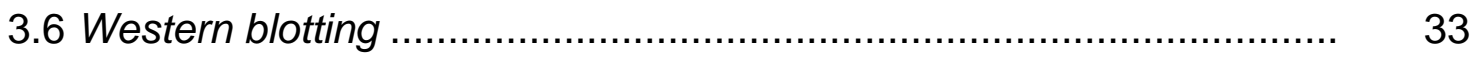

3.7 Ensaio duplo de MPF e MAPK ...................................................... 
3.8 Imunofluorescência para a detecção das proteínas p34 ${ }^{\text {cdc2 }}$, ciclina B1 e MAPK

3.9 Delineamento Experimental. 35

3.10 Análise Estatística. 39

4 RESULTADOS

4.1 Experimento 1 - Efeito do bloqueio meiótico na expressão das proteínes $\mathrm{p} 34^{\mathrm{cdc}}$, ciclina B1 e MAPK

4.2 Experimento 2 - Efeito do bloqueio meiótico na expressão das proteínas p34 ${ }^{\mathrm{cdc} 2}$, ciclina B1 e MAPK

4.3 Experimento 3 - Efeito do bloqueio meiótico na atividade do MPF e da MAPK

4.4 Experimento 4 - Efeito do bloqueio meiótico na localização subcelular das proteínas p34 ${ }^{\mathrm{cdc} 2}$, ciclina B1 e MAPK

5 DISCUSSÃO 53

6 CONCLUSÕES 68

7 REFERÊNCIAS 69

APÊNDICE A - Tampões para o ensaio duplo de detecção de atividade de MPF e MAPK 


\section{INTRODUÇÃO}

O gameta feminino é central para várias biotecnologias ligadas à reprodução animal, desde a produção in vitro (PIV) de embriões, já utilizada em escala comercial em vários países incluindo o Brasil (DAYAN et al., 2000; RODRIGUES; GARCIA, 2000), até técnicas mais sofisticadas como clonagem e transgênese, mais restritas à pesquisa científica. Para que tenham sucesso, tais tecnologias dependem, entre outros fatores, da qualidade e da competência meiótica e de desenvolvimento dos oócitos, que por sua vez são influenciados pelas condições de cultivo in vitro.

Embora em muito tenham avançado as técnicas para a PIV, a produção de blastocistos para transferência ainda se mantém em torno de 30-40\%, enquanto que a produção in vivo chega a 60-80 \% (RIZOS et al, 2002a). Há diferenças ainda em termos de qualidade dos embriões e de taxas de prenhez (HOLM; CALLESEN, 1998).

Dentre as diversas etapas envolvidas na PIV, a maturação do oócito certamente merece destaque, visto que foi demonstrado que a proporção de embriões produzidos por PIV é influenciada pela qualidade intrínseca do oócito (RIZOS et al, 2002b). A compreensão dos mecanismos responsáveis pela maturação do oócito é, portanto, crítica para a identificação de estratégias para melhorar a competência para o desenvolvimento de oócitos maturados in vitro, conseqüentemente melhorando a eficiência de técnicas de reprodução assistida, usadas para animais domésticos, espécies silvestres e na medicina humana.

O bloqueio meiótico tem sido utilizado como forma de permitir ao oócito maior tempo para adquirir a competência para o desenvolvimento antes de submetê-lo à maturação in vitro. Para tanto, tem-se utilizado de inibidores de cinases dependentes de ciclinas (CDK), tais como a butirolactona I, que bloqueiam a atividade do fator promotor da maturação (MPF). Embora tal procedimento resulte na maior parte das vezes em desenvolvimento apenas similar a embriões oriundos de oócitos não tratados, tem se prestado como importante ferramenta para a pesquisa do desenvolvimento e da diferenciação do oócito (SIRARD, 2001). 
O MPF e a proteína cinase ativada por mitógenos (MAPK) são os principais fatores reguladores da maturação e suas atividades são direta (MPF) e indiretamente (MAPK) afetadas por tais inibidores de CDK (KUBELKA et al, 2000). O controle do ciclo celular meiótico depende em boa parte da existência das proteínas que constituem o MPF, a p34 $4^{\mathrm{cdc} 2}$ e a ciclina B1, e também da MAPK, representada pelas proteínas p44 e p42 (ERK1 e ERK2). Além disso, a localização específica dessas proteínas no citoplasma celular também parece estar envolvida no controle de suas atividades durante o ciclo celular em oócitos e embriões (MARANGOS; CARROLL, 2004; NAKAMURA et al, 2005).

Os objetivos deste estudo foram de avaliar o efeito do bloqueio da meiose de oócitos bovinos com o inibidor de CDK butirolactona I sobre: 1) a expressão de RNAm de p34 ${ }^{\text {cdc2 }}$ e ciclina B1; 2) expressão das proteínas p34 ${ }^{\text {cdc2 }}$, ciclina B1 e MAPK; 3) atividade de MPF e MAPK e 4) localização das proteínas $\mathrm{p} 34^{\mathrm{cdc} 2}$, ciclina B1 e MAPK. 


\section{REVISÃO DE LITERATURA}

\subsection{Foliculogênese e Oogênese}

Nos mamíferos, a oogênese tem início durante o desenvolvimento fetal. Em bovinos, por volta dos 80 dias de gestação inicia-se a meiose (RÜSSE, 1983). O ciclo celular, no entanto, é bloqueado na prófase da meiose I, conhecido também como estádio de vesícula germinativa (VG), e assim permanece por meses ou anos até a puberdade. Pouco antes da ovulação, os oócitos são estimulados a retomar a meiose em resposta à onda pré-ovulatória de hormônio luteinzante (LH) e o ciclo celular progride até o estádio de metáfase II (MII), em que e novamente bloqueado. Este ciclo só será reiniciado e completado, após a ovulação, quando houver a fecundação pelo espermatozóide que provoca a sua ativação. Uma vez ativado o oócito completa a meiose e inicia os ciclos mitóticos do desenvolvimento embrionário.

A foliculogênese, por usa vez, inicia-se com a formação dos folículos primordiais, quando uma única camada de células pavimentosas (células prégranulosas) se posiciona em torno do oócito primário por volta dos 90 dias de gestação em bovinos (MEYES, 2002). Esta estrutura tem um diâmetro de cerca de $40 \mu \mathrm{m}$ (Van WEZEL; RODGERS, 1996), contendo um oócito de cerca de 30 $\mu \mathrm{m}$ (PICTON, 2001). Posteriormente, as células tornam-se cubóides (células da granulosa) dando origem ao folículo primário aos 140 dias de gestação. Iniciase a formação da zona pelúcida e das junções comunicantes entre as células da granulosa e o oócito (RÜSSE, 1983). Em torno de 210 dias de gestação, as células foliculares multiplicam por mitose dando origem ao folículo secundário, que apresenta pelo menos duas camadas de células da granulosa e um oócito de 50-60 $\mu \mathrm{m}$ (HYTTEL et al, 1997). Na fase seguinte, começa a surgir uma cavidade preenchida com líquido (antro), dando origem ao folículo antral ou terciário aos 230 dias de gestação (RÜSSE, 1983). O folículo tem agora cerca de 120-280 $\mu \mathrm{m}$ de diâmetro (MONNIAUX et al, 1997). Quando o folículo atinge 〜 $3 \mathrm{~mm}$ de diâmetro, o oócito chega a cerca de $120 \mu \mathrm{m}$, reduzindo muito seu 
ritmo de crescimento e cessando a sua atividade de síntese de RNA (HYTTEL et al, 1997). Daí por diante, o folículo cresce em tamanho até atingir o diâmetro pré-ovulatório (15-20 mm) enquanto o oócito tem um pequeno crescimento (ARLOTTO et al, 1996). Após o pico de LH, será retomada a meiose do oócito nele contido, que será ovulado em metáfase II (CALLESEN et al, 1986).

\subsubsection{Crescimento do oócito}

A fase de crescimento do oócito começa juntamente com crescimento do folículo e está quase completa quando ocorre a formação do antro. Durante esse período o oócito bovino aumenta de tamanho dos $35 \mu \mathrm{m}$ até cerca de $120 \mu \mathrm{m}$ de diâmetro (HYTTEL et al, 1997). Essa fase se caracteriza não só pelo aumento do tamanho do oócito ainda bloqueado na meiose I, mas também pelo aumento na quantidade de organelas e pela modificação da distribuição e morfologia das mesmas (HYTTEL et al, 1997). O oócito também sintetiza ativamente e armazena RNAs e proteínas essenciais para a futura maturação, fecundação e o início do desenvolvimento embrionário (SIRARD; COENEN, 1994). Essa fase coincide com o desenvolvimento do folículo primordial e cessa quando o folículo atinge $3 \mathrm{~mm}$. A partir daí o oócito cessa quase totalmente sua atividade transcricional (HYTTEL et al, 1997). Hyttel et al (1997) estudando a ultra-estrutura de oócitos ao longo de sua fase de crescimento in vivo antes de maturação, observaram que durante essa fase, onde o oócito encontra-se dentro de um folículo também em crescimento, ocorre uma série de eventos que incluem: desenvolvimento de organelas e inclusões tais como retículo endoplasmático liso, complexo de Golgi, vesículas, gotículas de lipídios, grânulos corticais; formação da zona pelúcida; modificação morfológica das mitocôndrias; formação das gap junctions (junções comunicantes) com as células da granulosa. Além disso, os oócitos acumulam transcritos e proteínas necessários para a competência para o desenvolvimento que correspondem à intensa atividade do nucléolo. Quando o oócito atinge o diâmetro de $110 \mu \mathrm{m}$, já ao fim da fase de crescimento, o nucléolo vai sendo inativado. 


\subsubsection{Capacitação do oócito}

A etapa entre o final do crescimento e o início da maturação in vivo com o pico de LH tem sido chamada de capacitação oocitária (HYTTEL et al, 1997; DIELEMAN et al, 2002). Nesse período em que praticamente cessa a síntese de RNA, ocorre uma série de modificações ultraestruturais fundamentais para a futura competência do oócito em desenvolver-se em um embrião viável. Nessa fase, observa-se que embora o oócito praticamente não cresça nem sintetize RNAs, o folículo terciário que o contém continua seu crescimento até um diâmetro próximo ao ovulatório (HYTTEL et al, 1997). Os eventos moleculares desse período são ainda desconhecidos e o oócito é ainda mantido em seu bloqueio meiótico na prófase I.

Blondin et al (1997) estudando o efeito do intervalo entre o abate e a recuperação dos oócitos dos ovários, observaram que melhores resultados poderiam ser obtidos mantendo os oócitos dentro dos folículos ovarianos por até 4 horas após o abate, comparativamente aos puncionados imediatamente após o abate. Concluíram neste estudo, que a aquisição de competência para o desenvolvimento pode ocorrer, em parte, antes mesmo da maturação in vitro. Os estudos do Blondin et al (2002) in vivo, também reforçam essa observação. Trabalhando com intervalos variáveis entre o tratamento de superovulação de vacas e a aspiração folicular guiada por ultra-som, seguida de maturação, fecundação e o cultivo in vitro, observaram que intervalos maiores levavam a maiores taxas de desenvolvimento, alcançando até cerca de $80 \%$ de blastocistos. Rizos et al (2002a,b), concluíram que a qualidade dos embriões obtidos na PIV seria relacionada ao sistema de cultivo in vitro, mas que as taxas de desenvolvimento (porcentagem de blastocistos) seria relacionada à qualidade intrínseca do oócitos antes mesmo da maturação.

Tais observações correspondem bem às conclusões dos estudos de Assey et al (1994), onde oócitos de folículos dominantes antes da onda de LH e, portanto, antes da maturação, sofrem modificações nucleares e citoplasmáticas envolvidas com a competência para o desenvolvimento.. No entanto, no período entre o final do crescimento do oócito até a onda préovulatória de LH que estimula a retomada da meiose e início da maturação 
oocitária, o oócito não entra numa total quiescência. Algumas modificações são observadas e incluem redução dos microvilos e do complexo de Golgi, retração das ligações com as células da granulosa, aumento do espaço perivitelínico, aumento da quantidade de gotículas de lipídios, início do deslocamento dos grânulos corticais para a periferia, ondulação da membrana nuclear e modificação da morfologia do nucléolo. Essa modificação nucleolar poderia estar relacionada a uma retomada de sua atividade transcricional. Esse intervalo foi denominado de "capacitação oocitária" e estaria relacionado com a aquisição final de competência para o desenvolvimento pelo oócito (HYTTEL et al, 1997).

\subsubsection{Maturação do oócito}

A maturação do oócito compreende o período logo após o pico ovulatório de LH quando o oócito retoma a meiose e passa pelas modificações finais que o tornam apto a ser fecundado por um espermatozóide. Compreende dois aspectos chamados de maturação nuclear e maturação citoplasmática.

\subsubsection{Maturação nuclear}

A maturação nuclear compreende o processo de reversão do primeiro bloqueio meiótico do oócito em vesícula germinativa (VG) até o segundo bloqueio meiótico em metáfase II (MII). Inicia-se no momento em que ocorre a retomada da meiose a partir do estádio de diplóteno da prófase I, marcada pela condensação dos cromossomos e rompimento da vesícula germinativa (RVG), ou seja, do envelope nuclear. Após o RVG, o oócito passa pelo estádio de diacinese, metáfase I (MI), anáfase I (Al), telófase I (TI), completando a primeira divisão meiótica, e então, rapidamente, passa para a MII da segunda divisão meiótica, quando há novo bloqueio do ciclo celular (segundo bloqueio meiótico). Ao longo desse processo, os cromossomos homólogos (2n) são 
divididos em dois grupos, com a metade do número original de cromossomos. Ao término da primeira divisão meiótica o citoplasma é dividido assimetricamente (CAN et al., 2003), gerando duas células de tamanhos diferentes: uma pequena chamada de corpúsculo polar e outra grande, o oócito secundário. Cada uma das células contém a metade do número de cromossomos da espécie. Ao término da maturação nuclear o oócito permanece nesse estádio do ciclo celular (MII) até a fecundação (MAYES; SIRARD, 2001) ou ativação partenogenética (YI; PARK, 2005). A maturação nuclear pode ser avaliada diretamente pela observação da configuração de cromatina no núcleo.

\subsubsection{Maturação citoplasmática}

Além da progressão da meiose, que caracteriza morfologicamente a maturação do oócito e que por si só não garante o desenvolvimento embrionário futuro, o mesmo sofre modificações em seu citoplasma denominadas maturação citoplasmática.

A maturação citoplasmática compreende as mudanças estruturais e moleculares que ocorrem no citoplasma oócito do estádio de VG até o fim da MII. A avaliação dessa maturação pode ser feita indiretamente pela habilidade do oócito maduro em clivar e desenvolver-se a blastocisto após fecundação ou ativação partenogenética. Outros parâmetros morfológicos indiretos como a expansão das células do cumulus (CC), a velocidade de extrusão do primeiro corpúsculo polar e aumento do espaço perivitelínico, também podem ser utilizados para avaliação da maturação citoplasmática (KRUIP et al, 1983).

As modificações ultraestruturais dizem respeito a uma reorganização citoplasmática, em que a maioria das organelas migra pelos microtúbulos e microfilamentos. As mitocôndrias e o complexo de Golgi, que se localizam mais perifericamente no oócito imaturo, migram e se distribuem numa posição perinuclear. Os grânulos corticais, produzidos pelo complexo de Golgi e situados originalmente no centro do oócito, migram para periferia do mesmo e ancoramse na membrana citoplasmática (CRAN; ESPER, 1990). 
As mudanças moleculares também são necessárias para que os oócitos possam prosseguir pelo processo de maturação. Entre as proteínas mais importantes que regulam o mecanismo de maturação estão as do complexo MPF (fator promotor da maturação) e as proteínas da família MAPK (proteína cinase ativada por mitógenos) (SHENG et al, 2002).

O MPF é um dos principais reguladores das alterações morfológicas que ocorrem durante a maturação do oócito, regulando a condensação dos cromossomos, o rompimento do envelope nuclear e a reorganização dos microtúbulos (KIM et al, 2000). Em oócitos em estádio de VG (imaturos), o MPF mantém-se com baixa atividade. Na retomada da meiose, este torna-se ativo atingindo máxima atividade em MI. Sofre depois um declínio transitório entre MI e MII e nessa última fase mantém-se novamente em atividade máxima (MOTLIK et al, 1998). Sua inativação em oócitos em estádio de MIl é induzida pela fecundação ou ativação paternogenética e é necessária para que ocorra o desbloqueio da meiose e sua conclusão (TAIEB et al, 1997).

$O$ que desencadeia a ativação do MPF, que caracteriza bioquimicamente a retomada da meiose e, conseqüentemente, o início da maturação, parece ser a concentração de AMPc no complexo cumulus-oócito. Quando há uma redução dos níveis de AMPc, finda a inibição sobre a atividade do MPF (GOREN; DEKEL, 1994). Uma vez ativo, o MPF desencadeia os eventos observados na maturação nuclear.

A via da MAPK também é ativada universalmente durante a maturação meiótica. Atua na fosforilação de diversos substratos incluindo fatores de transcrição e proteínas do citoesqueleto (ROUX; BLENIS, 2004). Em oócitos de bovinos sua ativação ocorre com a proximidade do rompimento da VG, apresentando um aumento gradual até 12-14 horas de maturação e se mantém estável até o seu final. Isso sugere que a MAPK não é requerida para o reinício da meiose, mas é essencial em eventos pós-rompimento da VG (KUBELKA et al, 2000). 


\subsection{Controle da maturação}

Durante o crescimento, a "capacitação" e a maturação do oócito, diversas moléculas de RNA e proteínas são sintetizadas e armazenadas. Essas moléculas vão dar suporte à maturação e ao desenvolvimento após a fecundação, até que o genoma do embrião se torne transcricionalmente ativo e as mensagens derivadas do embrião comecem a regular a embriogênese (CHA; CHIAN, 1998; MEIRELLES et al, 2004; MERMILLOD et al, 2000). A maioria dos RNAm (ácido ribonucléico mensageiro) no oócito é sintetizada e acumulada durante o período de crescimento do oócito (De SOUSA et al, 1998). Esse metabolismo no oócito é caracterizado pela transcrição e pela tradução ativa durante o período pré-ovulatório. Entretanto, a transcrição gênica bovina cessa antes da ovulação, assim, o oócito, o zigoto e o embrião com menos de 16 blastômeros são dependentes do pool dos RNAs e das proteínas acumuladas durante o período de crescimento e de maturação do oócito (GANDOLFI; GANDOLFI, 2001; LONERGAN et al, 2003 MEMILI; FIRST 2000).

Oócitos de muitas espécies dependem da síntese e da ativação de uma variedade de proteínas para que possam ingressar e prosseguir no processo de maturação. Entre as proteínas mais importantes que regulam o mecanismo da maturação oocitária estão as proteínas do complexo MPF e $s$ da família das MAPK (JONES, 2004; SHENG et al, 2002; TIAN et al, 2002)

\subsubsection{MPF}

O MPF é um heterodímero composto por uma cinase catalítica (p34 $4^{\mathrm{cdc} 2}$ ou CDK1) e uma subunidade de ciclina $B$ regulatória (ABRIEU et al, 2001; JONES, 2004). Há ao menos três tipos de ciclinas B (B1, B2 e B3), e nos mamíferos parece que a ciclina B1 é a principal responsável pela atividade do complexo MPF. Embora a ligação da CDK1 com a ciclina B1 seja necessária, 
não é o suficiente para desencadear a atividade do complexo MPF (CASTRO et al, 2001; JONES, 2004), que é dependente dos mecanismos subseqüentes: fosforilação da CDK1 nos resíduos de tirosina 15 (Y15), treonina 14 (T14), treonina 161 (T161) e a posterior desfosforilação dos resíduos Y15 e T14 (JOSEFSBERG; DEKEL, 2002; KIKUCHI et al, 2000; VAILLANT et al, 2001;).

A variação da atividade do MPF pode ser detectada nos oócitos bovinos durante a maturação. Sua atividade é baixa em VG passando a ser observada no início do rompimento da VG. Alcança um pico no estádio de metáfase I e declina sua atividade durante a transição entre os estádios de metáfase I e metáfase II (KUBELKA et al, 2000), reativando para entrada do oócito em metáfase II. Sua inativação nos oócitos em estádio de metáfase II é induzida pela fecundação ou pela ativação paternogenética (ABRIEU et al, 2001; KIKUCHI et al, 2000; KUBELKA et al, 2000; LEDAN et al, 2001). A inativação abrupta do MPF é considerada como um disparador necessário para o escape da meiose bloqueada em metáfase II (TAIEB et al, 1997).

O processo de desorganização do heterodímero do complexo MPF independe da sua ativação catalítica, que é causada geralmente pela proteólise da ciclina B. Em oócitos fecundados de camundongos e de suínos, a degradação da ciclina B foi claramente relacionada com a inativação do complexo MPF (KIKUCHI et al, 1999; WINSTON, 1997).

O MPF é um dos principais reguladores das alterações morfológicas durante a maturação oocitária, regulando a condensação dos cromossomos, o rompimento do envelope nuclear, a reorganização dos microtúbulos e outras organelas citoplasmáticas com a participação de outras proteínas (KANO et al, 2000; KIM et al, 2000; KRISCHEK; MEINECKE, 2002; KUBELKA et al, 2002; LEFEBVRE et al, 2002).

\subsubsection{MAPK}

Um segundo grupo importante de proteínas que estão envolvidas na progressão da meiose pertencem à família das serina/treonina cinases, as proteínas cinases ativadas por mitógenos (MAPK) (KUBELKA et al, 2000). 
Essas proteínas são ativadas dentro de vias específicas de transdução de sinais por sinais extracelulares (NEBREDA; FERBY, 2000). Por esta razão, a MAPK também é chamada de ERK (cinase regulada por sinal extracelular suas variantes, ERK1/2 - p44/p42 kDa) (KRISCHEK; MEINECKE, 2002). A ampla faixa de atuação das MAPKs é mediada pela fosforilação de diversos substratos, incluindo fosfolipases, fatores de transcrição e proteínas do citoesqueleto. As MAPKs também catalisam a fosforilação e a ativação de diversas proteínas cinases, denominadas de proteínas cinases ativadas pelas MAPKs, que representam um adicional enzimático de vários espectros em diferentes células (ROUX; BLENIS, 2004).

A via MAPK é ativada universalmente durante a maturação meiótica em oócitos de vertebrados. A ativação da MAPK em oócitos bovinos ocorre após 8 horas de cultivo in vitro e apresenta um aumento gradual até 12-14 horas e mantém-se estável até o final da maturação (KUBELKA et al, 2000).

As duas principais isoformas (ERK1/2) da MAPK são ativadas com a proximidade do rompimento da VG em oócito bovinos (KUBELKA et al, 2000). Isso sugere que a MAPK não é requerida para o reinício da meiose, mas é essencial em eventos pós-rompimento da VG (KANO et al, 2000; LEFEBVRE et al, 2002). Porém, a injeção de MAPK ativa em oócitos de suíno ou de bovino induz o rompimento da VG, indicando que essa proteína promove o reinício da meiose em condições especiais (FISSORE et al, 1996; INOUE et al, 1998).

\subsection{Competência oocitária}

A competência para o desenvolvimento se refere à capacidade do oócito em produzir um novo indivíduo após a fecundação (HYTTEL et al, 1997). Ao longo do desenvolvimento folicular há um aumento gradual da competência para o desenvolvimento (GANDOLFI; GANDOLFI, 2001). Dentre vários fatores, o tamanho do folículo e do oócito parecem ter estreita correlação com a competência oocitária (HYTTEL et al, 1997).

Lonergan et al (2001), obtiveram 66\% de blastocistos a partir de oócitos de folículos maiores $(6-8 \mathrm{~mm})$ e $34 \%$ a partir de folículos menores $(2-6 \mathrm{~mm})$. 
Yang et al (1998) demonstraram que oócitos oriundos de folículos pequenos (<2 mm) são incompetentes para o desenvolvimento tanto após a fecundação in vitro (FIV) como após ativação partenogenética e concluíram que a incompetência dos oócitos de folículos pequenos é devido tanto ao núcleo quanto ao citoplasma.

Oócitos de diferentes diâmetros também apresentam competência meiótica e de desenvolvimento distintos. Na medida em que o oócito aumenta de diâmetro, este vai adquirindo progressiva e seqüencialmente a capacidade de retomar a meiose (quebra da VG), progredir até MI, MII e, finalmente, de desenvolver-se em um embrião (HYTTEL et al, 1997). Parece haver um limite mínimo de competência em que oócitos estão aptos a desenvolver após a fecundação. Em bovinos esse limite ocorre quando os oócitos atingem um diâmetro mínimo de 110-120 $\mu \mathrm{m}$ e que tenham sido obtidos de folículos de pelo menos 3 mm de diâmetro (HYTTEL et al, 1997). Isso indica que a competência para retomar e concluir a meiose, e posteriormente para ser fecundado e desenvolver-se em um embrião viável, é adquirida de forma gradual com o crescimento do oócito e do folículo ovariano. Pode-se dizer, porém, que a competência para a maturação citoplasmática pode ser adquirida juntamente, mas não é coincidente com a maturação nuclear. Isso é patente uma vez que se observa que uma proporção bem menor de oócitos atinge o estádio de blastocisto (30-40\%) em relação àquela que atinge a maturação nuclear (>80\% de MII).

A competência é dependente do estoque e utilização correta das moléculas (RNAs e proteínas) oocitárias. Sabe-se que antes da ativação do genoma embrionário o desenvolvimento é comandado por RNAs e proteínas estocadas no oócito durante o período de crescimento e maturação. Tais genes são transcritos de forma estádio e tempo dependente. Dos genes transcritos, muitos estão envolvidos com regulação da transcrição e tradução, modificação pós-tradução de proteínas, regulação do ciclo celular, entre outros (WRENZYCKI et al, 2007).

Uma das formas de controlar a utilização de RNAs e proteínas de forma ordenada ao longo da maturação, fecundação e desenvolvimento embrionário até a transição materno-zigótica, é a localização dessas moléculas em regiões específicas do citoplasma (BREVINI et al, 2007a,b). Nakamura et al (2005) 
relataram que a atividade do MPF também é regulada pela localização espacial de suas subunidades no citoplasma celular. A localização da MAPK no citoplasma também é variável de acordo com seu estado de atividade (GOTO et al, 2002; INOUE et al, 1998; LU et al, 2002;). A ciclina B1 (MARANGOS; CARROLL, 2004) e a p34 ${ }^{\text {cdc2 }}$ (HUO et al, 2005) também têm localização variável dependendo da fase de maturação do oócito. A capcidade de desenvolvimento do oócito em um embrião é, portanto, um evento multifatorial com muitos destes fatores a seus respectivos papéis ainda insuficientemente conhecidos.

\subsection{Bloqueio meiótico}

Na produção de embriões in vitro, os oócitos são aspirados de folículos entre 2 e 6 mm de diâmetro. Nessas condições eles estariam sendo removidos dos folículos antes de completarem a foliculogênese, o que seria provavelmente, um dos fatores envolvidos na baixa produção de embriões in vitro. Além disso, os oócitos não passariam pelo período de capacitação que ocorre in vivo (DIELEMAN et al, 2002; HENDRICKSEN et al, 2000), em que modificações ocorrem emquanto o oócito mantido em VG e o folículo cresce ate a ovulação ocorrer.

In vitro, ocorre o reinício espontâneo da meiose porque o oócito é liberado da influência dos inibidores provenientes do folículo (KOTSUJ। et al, 1994). No entanto, a maturação in vitro resulta em uma redução na produção de embriões, sugerindo que nem todos os oócitos conseguem maturar adequadamente (maturação citoplasmática).

Para contornar a foliculogênese interrompida a que os oócitos são submetidos, uma alternativa seria mantê-los por um determinado período com a mesma configuração nuclear daquela encontrada nos folículos. Para tal, os oócitos seriam submetidos ao bloqueio meiótico, evitando a retomada da meiose logo após a sua remoção dos folículos, para que tenham o tempo necessário para sofrerem as mudanças essenciais antes de serem submetidos à maturação in vitro. 
Inibidores específicos de cinases dependentes de ciclinas (CDKs) tais como butirolactona I podem ser utilizados no cultivo de pré-maturação antes de submeter os oócitos à maturação, fecundação e ao desenvolvimento embrionário. Adona e Leal (2004) relataram que a BLI pode ser utilizada em baixa concentração pra bloquear de forma segura e eficaz a meiose em oócitos de bovinos, prestando-se como ferramenta para estudar as condições de cultivo para produção de embriões in vitro.

\subsubsection{In vivo}

Está bem estabelecido que o oócito, enquanto mantido dentro do ambiente folicular, permanece bloqueado em VG. O AMPc presente em altos níveis dentro do oócito tem sido apontado como o principal responsável pela manutenção do bloqueio da meiose do oócito até o momento da maturação, visto que sua redução é um sinal necessário para a maturação oocitária (CONTI et al, 1998; EYERS et al, 2005). O AMPc é uma molécula sinalizadora intracelular que exerce um importante controle na meiose em mamíferos, anfíbios e em alguns invertebrados (BILODEAU-GOESEELS, 2003). As células da granulosa seriam responsáveis pela síntese do AMPc que passaria ao oócito pelas gap junctions (EDRY et al, 2006). Por outro lado, observou-se que o oócito também possui a enzima necessária para a síntese desse nucelotídeo (adenilato ciclase), sendo, portanto, capaz de sua produção (MEHLMAN et al, 2005). Ainda não foi provado se uma ou ambas as vias são utilizadas para manter o oócito em VG, porém está claro que altos níveis de AMPc são necessários para tal bloqueio e que o mesmo ocorre pela ação do AMPc em manter o MPF inativado (DUCKWORTH et al, 2002). 


\subsubsection{In vitro}

Nos procedimentos de maturação in vitro (MIV), utilizam-se usualmente folículos entre 3-6 mm de diâmetro, no entanto, é provável que uma parte considerável desta população seja incompetente para o desenvolvimento. Os oócitos ao serem removidos do ambiente folicular, deixam de ter o sinal que mantém o bloqueio meiótico e reiniciam espontaneamente a meiose. Este reinício poderia ser, em muitos casos, precoce, ou seja, o oócito ainda não estaria apto para maturar eficientemente e, portanto, para fecundar e desenvolver (HENDRIKSEN et al 2000; HYTTEL et al, 1997). Possivelmente seria necessário manter os oócitos por mais tempo em VG para que tenham tempo suficiente para adquirir a competência.

Lonergan et al (1997) e Hendriksen et al (2000) sugeriram que uma prématuração in vitro poderia permitir que oócitos, que tiveram o final de seu desenvolvimento encurtado pela remoção precoce do ambiente folicular, fossem capazes de "alcançar" os estádios finais do desenvolvimento. Mantendo-se os oócitos bloqueados seria possível procurar mimetizar o período da capacitação.

A regulação das atividades enzimáticas de uma série de proteínas cinases e fosfatases controla a meiose em oócitos de mamíferos. Desta forma, a meiose pode ser bloqueada por drogas que mantenham altas concentrações de AMPc no interior do oócito (BILODEAU-GOESEELS, 2003), por inibidores não específicos da síntese protéica (MEINECKE et al, 2001; SAEKI et al, 1997), de proteínas cinases (ANDRIESZ et al, 2000; DODE; ADONA, 2001) ou por inibidores específicos do MPF (ADONA; LEAL, 2004; HASHIMOTO et al, 2002; KUBELKA et al, 2000).

A manipulação dos níveis de AMPc tem tido algum sucesso na prématuração de oócitos de camundongos (NOGUEIRA et al, 2003) e humanos (NOGUEIRA et al, 2006). Oócitos bovinos, porém, parecem ser menos sensíveis à manipulação dos níveis de AMPc para controlar a meiose. O bloqueio é possível por períodos mais curtos de tempo e parece retardar a perda de comunicação entre as células da granulosa e o oócito, que ocorre 
logo após a remoção do oócito do folículo (THOMAS et al, 2004). Grupen et al (2006), porém, obtiverem resultados semelhantes entre a milrinona (inibidor de fosfodiesterase) e butirolactona I (inibidor de CDK) em termos de bloqueio, reversibilidade e desenvolvimento embrionário após tratar oócitos suínos na primeira metade do período de maturação.

Inibidores de síntese protéica como a cicloheximida e de fosforilação protéica como a 6-DMAP (AVERY et al, 1998; DODE; ADONA, 2001; LONERGAN et al, 1997, 1998; SAEKI et al, 1997) também foram utilizados para manter os oócitos em bloqueio meiótico pré-maturação. No entanto, embora obtivessem bloqueio reversível e desenvolvimento de blastocistos, o desenvolvimento foi inferior aos controles. Estas substâncias são de amplo espectro e poderiam estar interferindo com outras vias bioquímicas/metabólicas importantes. Como a retomada da meiose é caracterizada pela ativação do MPF, um inibidor específico de MPF permitiria a manutenção dos oócitos em bloqueio meiótico.

Algumas drogas inibem especificamente a fosforilação do MPF, mantendo-o inativo e, conseqüentemente, permitindo um bloqueio meiótico sem interferência com outras proteínas do oócito. A butirolactona I (BLI) é uma purina derivada de micélios de Aspergillus $s p$ e inibe especificamente cinases dependentes de ciclinas (MOTLIK et al, 1998). Além desta, existem seus análogos sintéticos como a roscovitina (ROS) e a bohemine (BOH).

A ROS (MERMILLOD et al, 2000), a BLI (LONERGAN et al, 2000; KUBELKA et al, 2000; MOTLIK et al, 2000), a associação das duas (PONDERATO et al, 2001) e a BOH (ADONA; LEAL, 2004) já foram utilizadas com algum sucesso para bloquear a meiose em oócito de vacas adultas e mesmo de bezerras (ALABARRACín et al 2005; DONNAY et al, 2004). Essas drogas também já foram utilizadas em outras espécies como suínos (JU et al, 2003; Le BEAUX et al, 2003; ROMAR; FUNAHASHI, 2006, WU et al, 2002), eqüinos (HINRICHS et al, 2002) e caprinos (; HAN et al, 2006; JIMENEZMACEDO et al, 2006).

A meiose é inibida de forma eficiente e reversível por períodos variados de tempo, de $24 \mathrm{~h}$ (KUBELKA et al, 2000; LONERGAN et al, 2000; MERMILLOD et al, 2000), $48 \mathrm{~h}$ (KUBELKA et al, 2000) e até $70 \mathrm{~h}$ (PAVLOK et al 2000). No entanto, as taxas de desenvolvimento a blastocisto nesses 
trabalhos não chegaram a ser melhores que as obtidas sem o uso de inibidores, mantendo-se em 30-40\% (LONERGAN et al, 2000; MERMILLOD et al, 2000; PONDERATO et al, 2001). Hashimoto et al (2002), por outro lado, conseguiram um aumento significativo nas taxas de desenvolvimento e número de células dos blastocistos em relação aos controles, incluindo soro fetal bovino no meio de inibição com $100 \mu \mathrm{M}$ de $\mathrm{BLI}$ e reduzindo a tensão de $\mathrm{O}_{2}$ durante o cultivo de pré-maturação.

Embora não se tenha conseguido melhorar o desenvolvimento embrionário (ADONA, 2005), o bloqueio da meiose pode ser usado como ferramenta de pesquisa como modelo para compreensão dos mecanismos envolvidos no envelhecimento do oócito (TATONE et al, 2006), em estudos sobre o controle da identificação de marcadores de competência (SANFINS et al, 2004), o efeito de diferentes fatores durante o período de bloqueio da meiose como hormônios (BEKER van WOUNDENBERG et al, 2006; COENEN, 1994; SIRARD) ou fontes energéticas (BILODEAU-GOESEELS, 2006), controle dos vários processos envolvidos na maturação do oócito como condensação de cromossomos (JELIKOVÁ; KUBELKA, 2006; KUBELKA et al, 2002), expansão das células do cumulus (VIGNERON et al, 2003), vias de sinalização (VIGNERON et al, 2004b), tradução, transcrição (VIGNERON et al, 2004a) e poliadenilação de RNAm (LEQUARRE et al, 2004). Além disso, o bloqueio pode ser utilizado para flexibilização de horários de maturação mais convenientes para procedimentos de FIV ou clonagem (IMAI et al, 2002; LAGUTINA et al, 2002), transporte de oócitos aspirados em locais distantes dos laboratórios de PIV (HASHIMOTO et al, 2003). Mais conhecimentos acerca do oócito e do ambiente folicular a que é exposto in vivo, aliado aos dados obtidos de estudo in vitro, poderão auxiliar no desenvolvimento de condições mais eficientes para a produção de embriões in vitro. 


\section{MATERIAL E MÉTODOS}

\subsection{Local do Experimento}

O experimento foi desenvolvido no Laboratório de Histologia do Departamento de Ciências Básicas da Faculdade de Zootecnia e Engenharia de Alimentos (FZEA) da Universidade de São Paulo (USP) - Campus de Pirassununga.

\subsection{Coleta dos ovários e seleção dos oócitos}

Os oócitos foram obtidos de ovários de vacas zebus ou azebuadas oriundos de frigoríficos do Estado de São Paulo numa distância de até 200 km da FZEA. Os ovários foram coletados logo após o abate e transportados em solução fisiológica estéril ( $\mathrm{NaCl}$ 0,9\% - Sigma, S9625) acrescida de antibióticos (100 Ul/ml de penicilina - Sigma, P7794 e $100 \mu \mathrm{g} / \mathrm{ml}$ de estreptomicina Sigma, S9137) a uma temperatura de $30^{\circ} \mathrm{C}$. No laboratório, os ovários foram lavados com a solução semelhante ao do transporte mais etanol $70 \%$. Os folículos de 2 a $6 \mathrm{~mm}$ de diâmetro foram aspirados com auxílio de uma agulha de 18 "G" (1,20 X $40 \mathrm{~mm})$ acoplada a uma seringa descartável de $10 \mathrm{ml}$. O líquido folicular contendo os oócitos foi depositado em tubos cônicos de $50 \mathrm{ml}$ (Cellstar, 227261) e mantido em repouso para decantação por 5 minutos. A porção superior do líquido foi retirada e na porção restante foram adicionados 3 a $5 \mathrm{ml}$ de meio H199 (TCM199 com 25 mM de Hepes - Sigma, M2520) acrescidos de $100 \mathrm{Ul} / \mathrm{ml}$ de penicilina, $100 \mu \mathrm{g} / \mathrm{ml}$ de estreptomicina e 1\% de soro fetal bovino (SFB, Gibco, 26140-079). Posteriormente, o material do tubo foi transferido para placas de Petri (60 x 15 mm - Falcon, 353002) onde foi feita a busca dos oócitos sob estereomicroscópio para avaliação e classificação dos mesmos. Somente oócitos classificados como graus I e II (DE LOOS et al., 
1991), com três ou mais camadas de células do cumulus oophorus e citoplasma uniforme, foram utilizados para os experimentos.

\subsection{Bloqueio da meiose}

Para o bloqueio da meiose os oócitos foram cultivados in vitro com 10 $\mu$ M de butirolactona I (BLI) diluída em meio B199 [TCM199 (Sigma, M5017) acrescido de 26 mM de $\mathrm{NaHCO}_{3}$ (Sigma, S5761)] suplementado com 0,2 mM de piruvato de sódio (Sigma, P5280). A BLI (Biomol, 87414-49-1) foi preparada como uma solução estoque de 50 mM em dimetilsulfóxido (DMSO-Sigma, D5879) e rediluída em B199 para 5 mM em B199 com $10 \mu \mathrm{g} / \mathrm{ml}$ de gentamicina, aliquotado em tubos para microcentrífuga e conservado no freezer a $-20^{\circ} \mathrm{C}$. Para o cultivo a BLI foi rediluída para a concentração de uso $(10 \mu \mathrm{M})$ e os oócitos cultivados em gotas de $100 \mu \mathrm{l}$ ( \pm 20 oócitos por gota) sob óleo mineral (Sigma, M8410) em incubadora a $38,5^{\circ} \mathrm{C}$ e atmosfera de $5 \%$ de $\mathrm{CO}_{2}$ em ar e máxima umedade por um período de 24 horas.

\subsection{Maturação in vitro dos oócitos}

Para maturação in vitro (MIV), os oócitos selecionados foram cultivados em meio de maturação (MM) constituído de B199 suplementado com 10\% SFB, 5,0 $\mu \mathrm{g} / \mathrm{ml}$ de hormônio luteinizante ( $\mathrm{LH}$, Bioniche - Lutropin-V), 0,5 $\mu \mathrm{g} / \mathrm{ml}$ de hormônio folículo estimulante (FSH, Bioniche - Folltropin-V), 0,2 mM de piruvato de sódio e $10 \mu \mathrm{g} / \mathrm{ml}$ de neomicina (Sigma, P6148). Os oócitos foram maturados em microgotas de $100 \mu \mathrm{l}$ de MM (20 a 25 oócitos por gota) sob óleo mineral em incubadora a a $38,5^{\circ} \mathrm{C}$, atmosfera de $5 \% \mathrm{CO}_{2}$ em ar e máxima umidade por 24 horas. 


\subsection{Reação em cadeia de polimerase em tempo real}

Para a realização da reação em cadeia de polimerase (PCR) em tempo real, os oócitos foram congelados em grupos de 250 para avaliação dos RNAm transcritos para $\beta$-actina, p34 ${ }^{\text {cdc2 }}$, ciclina B1 e MAPK. Os oócitos foram primeiramente desnudados (remoção das células do cumulus) em tubo de $5 \mathrm{ml}$ com 0,3 ml de PBS livre de cálcio e magnésio com 0,1\% de PVA por agitação no vortex (5 minutos). Posteriormente, os oócitos desnudos foram lavados 5 vezes em PBS/PVA para garantir que células do cumulus não fossem congeladas junto com os oócitos. Os grupos de 250 oócitos foram lavados em

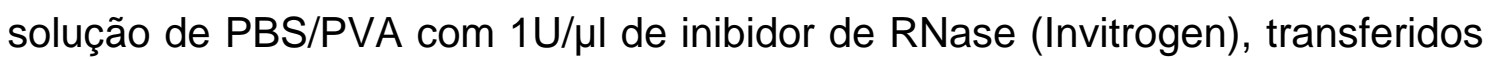
para microtubos com $1 \mu$ dessa solução, mergulhados no nitrogênio líquido e armazenados $\mathrm{a}-80^{\circ} \mathrm{C}$.

As amostras de oócitos foram depois submetidas à extração de RNA com o RNeasy Protect Mini Kit (Qiagen) de acordo com as instruções do fabricante. A transcrição reversa foi realizada utilizando a enzima Improm-II Reverse Transcriptase (Promega) seguindo as recomendações do fabricante. A reação para produção do cDNA foi realizada em termo-ciclador por 60 min a $42^{\circ} \mathrm{C}$, seguido de aquecimento a $70^{\circ} \mathrm{C}$ por 15 min e posterior resfriamento a $4^{\circ} \mathrm{C}$ para congelamento $\mathrm{a}-20^{\circ} \mathrm{C}$.

A quantificação dos genes transcritos foi feita por PCR em tempo real usando o kit SYBR green PCR master mix (Applied Biosystems) seguindo as recomendações do fabricante em equipamento da Applied Biosystems 7500 RT-PCR System. A temperatura de anelamento para todos os primers foi de $60^{\circ} \mathrm{C}$. As análises foram realizadas por meio de quantificação relativa, tomando-se como normalizador da expressão o gene constitutivo ß-actina. Os primers (Prodimol) foram sintetizados para o genes da $\beta$-actina, p34 ${ }^{\mathrm{cdc} 2}$, ciclina B1 e MAPK a partir de seqüências conhecidas do GenBank (Tabela 1). Os experimentos foram feitos em quatro repetições, tendo cada reação sido feita em triplicata.

Os produtos amplificados foram analisados também por eletroforese em gel de $2 \%$ de agarose para verificação dos tamanhos dos fragmentos e validação dos resultados obtidos pela PCR em tempo real. 
Tabela 1 - Primers utilizados para PCR em tempo real.

\begin{tabular}{ll}
\hline Gene & Primers \\
\hline \multirow{2}{*}{ B-actina } & F-5'-GGATGAGGCTCAGAGCAAGAGA-3' \\
& R-5'-TCGTCCCAGTTGGTGACGAT-3' \\
\hline \multirow{2}{*}{ p34 $^{\text {cdc2 }}$} & F-5'-GGAAGCTTAGCATCCCATGTC-3' \\
& R-5'-TCATTAAAGTACGGATGATTCAGTG-3' \\
\hline \multirow{2}{*}{ Ciclina B1 } & F-5'-ACACCTACACCAAGTTTCAAATCA-3' \\
& R-5'-ATCGTAGTCCAGCATAGTTAGTTCC-3' \\
\hline \multirow{2}{*}{ MAPK-1 } & F-5'-TGAACCACATTCTGGGTATTCTT-3' \\
& R-5'-TGCTCCACCTCGATCCTCTT-3' \\
\hline
\end{tabular}

\subsection{Western blotting}

Os oócitos foram desnudados e grupos de 30 foram suspensos em $10 \mu \mathrm{l}$ de tampão de amostra (Apêndice $\mathrm{A} 1$ ), fervidos a $90^{\circ} \mathrm{C}$ por 5 min e a seguir armazenados congelados a $-20^{\circ} \mathrm{C}$ até o uso. As proteínas foram separadas por eletroforese em gel de $10 \%$ de policacrilamida-sódio duodecil sulfato (LAEMMLI, 1970). Posteriormente, foi feita e eletrotransferência para uma membrana de fluoreto de polivinilideno (PVDF, Millipore) que foi depois bloqueada com $5 \%$ de leite em pó desnatado (Nestlé) em salina tamponada com Tris (Invitrogen) (TBS) acrescida de 0,1\% de Tween-20 (USB) (TBS-T) por $1 \mathrm{~h}$. Após uma breve lavagem de $5 \mathrm{~min}$ em TBS-T, as membranas foram incubadas com os anticorpos primários (p34 ${ }^{\text {cdc2 }}$ 1:1000, ciclina B1 1:200 ou MAPK 1:750) diluídos em TBS-T por $2 \mathrm{~h}$. Depois de lavar as membranas $3 \times 15$ min em TBS-T, as mesmas foram incubadas com o anticorpo secundário de cabra anti-IgG de coelho conjugada à peroxidase (Santa Cruz Biotechnologies) diluída 1:4000 em TBS-T por $1 \mathrm{~h}$. Depois de lavadas novamente $(3 \times 15 \mathrm{~min}$ em TBS-T) as membranas foram incubadas em reagente quimioluminescente (Amersham) por 1 min e expostas a filme de raios-X (Amersham) por 5 min. As bandas presentes no filme foram analisadas pelo software Image Master Platinum v. 6.0 (Amersham) para densitometria das mesmas. 


\subsection{Ensaio duplo de detecção de atividade de MPF e MAPK}

As atividades de MPF e MAPK foram avaliadas indiretamente por ensaio de histona $\mathrm{H} 1$ e de proteína básica de mielina (MBP) (CHRISTMANN et al., 1994; KUBELKA et al., 2000), que são os substratos fosforilados pelas respectivas cinases. Grupos de cinco oócitos foram colocados em tubo de microcentrífga contendo $3 \mu \mathrm{l}$ do tampão de coleta (Apêndice A2) e congelados a $-70^{\circ} \mathrm{C}$ até serem utilizados para o ensaio.

Para a realização do ensaio, as amostras foram descongeladas e às mesmas foram adicionados $3 \mu$ do tampão de homogeneização (Apêndice A3). As amostras foram incubadas a $37^{\circ} \mathrm{C}$ por 15 min. Após esse período foram adicionados $4 \mu \mathrm{l}$ do tampão de reação (Apêndice A4) contendo $1 \mathrm{mg} / \mathrm{ml}$ de MBP (Sigma); 1mg/ml de histona H1 (Sigma) e 1,8 MBq/ml [gama- ${ }^{32} \mathrm{P}$ ] ATP (166 $\mathrm{TBq} / \mathrm{mM}$, Amersham). A reação prosseguiu por $30 \mathrm{~min}$ a $37^{\circ} \mathrm{C}$ antes de ser interrompida pela adição de $10 \mu$ l de tampão de amostra (Apêndice A4) $2 X$ concentrado (volume final $20 \mu \mathrm{l}$ ). Para a separação da histona H1 e da MBP, marcadas radioativamente, as amostras foram fervidas por 5 min a $95^{\circ} \mathrm{C}$ e levadas para eletroforese em gel de 12,5\% de policacrilamida-sódio duodecil sulfato (LAEMMLI, 1970).

O gel foi desidratado e exposto à placa de imagem do sistema de análise FUJI-FLA 2000g para detecção e posterior análise das bandas pelo software Image Gauge 3.1, Fuji Film. As atividades de oócitos controle em VG (atividade mínima) foram arbitrariamente determinadas como normalizadoras e as atividades das amostras foram determinadas como múltiplos destas.

3.8 Imunofluorescência para determinação das proteínas p34 ${ }^{\text {cdc2 }}$, ciclina B1 e MAPK

Os oócitos foram fixados em 3,7\% paraformaldeído em PBS/PVA por $1 \mathrm{~h}$ e depois permeabilizados em PBS/PVA contendo 0,5\% Triton X-100 por 30 
min. Foram depois incubados em soro de cabra (Sigma) a 10\% em PBS/PVA por 45 min e depois separadamente com cada anticorpo primário policlonal de coelho (p34 $4^{\mathrm{cdc} 2}$ 1:200, ciclina B1 1:50 ou MAPK 1:100, Santa Cruz Biotechnologies) diluído em PP (controles da reação apenas em PBS/PVA). Os oócitos foram lavados em PBS/PVA ( $3 \times 5 \mathrm{~min}$ ) e, posteriormente, incubados com o anticorpo secundário de cabra anti-lgG de coelho de conjugado ao FITC (1:100, Vector Laboratories) diluído em PBS/PVA por $1 \mathrm{~h}$ seguido de marcação do DNA com iodeto de propídio $(10 \mu \mathrm{g} / \mathrm{ml})$ por $10 \mathrm{~min}$. Os oócitos corados foram montados entre lâmina e lamínula em solução Vectahsield (Vector Laboratories) para reduzir a perda de fluorescência e avaliados sob microscópio de epifluorescência para detecção das diferentes proteínas nos mesmos.

\subsection{Delineamento Experimental}

Nesse trabalho foi avaliado o efeito do bloqueio da meiose na expressão de RNA e proteínas alem da atividade e distribuição de proteínas relacionadas ao controle do ciclo celular meiótico de oócitos bovinos. Foram comparados oócitos mantidos imaturos (bloqueado imaturo $=$ BVG) pelo cultivo por $24 \mathrm{~h}$ na presença de $10 \mu \mathrm{M}$ butirolactona I e os oócitos maturados in vitro após o bloqueio prévio da meiose (bloqueado maturado $=\mathrm{BMII}$ ). Foram ainda comparados oócitos obtidos logo após a aspiração folicular (controle imaturo = VG) e oócitos maturados in vitro sem bloqueio meiótico prévio (controle maturado $=$ MII).

Os diferentes grupos de oócitos foram avaliados, em experimentos distintos, quanto à:

1) Experimento 1: expressão dos genes $p 34^{\text {cdc2 }}$ e ciclina $B 1$, bem como do gene constitutivo $\beta$-actina, para determinar a expressão relativa dos genes do ciclo celular por PCR em tempo real. Foram avaliados pools de 250 oócitos por grupo em três repetições; 
2) Experimento 2: expressão das proteínas p34, ciclina B1 e MAPK por western blotting. Foram avaliados pools de 30 oócitos por grupo em três repetições;

3) Experimento 3: atividade das proteínas MPF e MAPK, por ensaio indireto, via detecção de fosforilação dos respectivos substratos (histona H1 e MBP). Foram avaliados pools de 5 oócitos por grupo coletados de 3 em 3 horas em três repetições;

4) Experimento 4: distribuição das proteínas p34, ciclina B1 e MAPK nos oócitos por imunofluorescência. Foram avaliados 15-20 oócitos por grupo, distribuídos em três repetições.

Esquemas resumidos dos grupos avaliados e das avaliações realizadas, encontram-se nas Figuras 1 e 2, respectivamente. 
Dia 0

Dia 1

Dia2
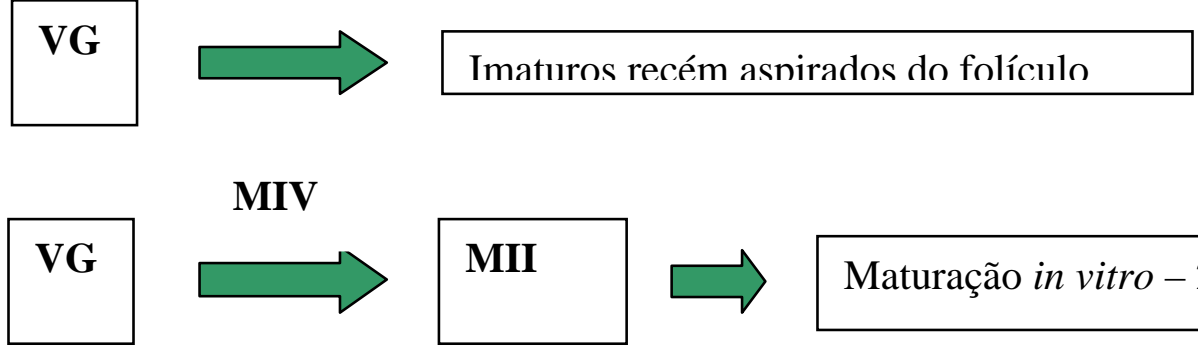

\section{MIV}

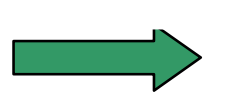

MII

$\square$ Maturação in vitro - 24 hs

Blnamein

VG

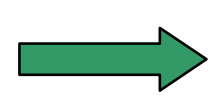

BVG

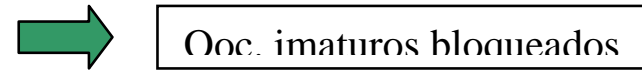

VG

\section{Bloqueio}

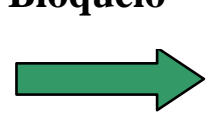

BVG

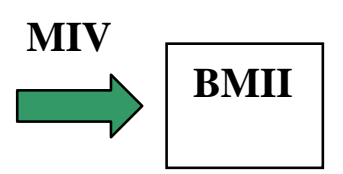

Ooc. bloqueados e maturados in vitro

Figura 1 - Diagrama representativo dos grupos experimentais. 


\section{$\underline{\text { Avaliações }}$}

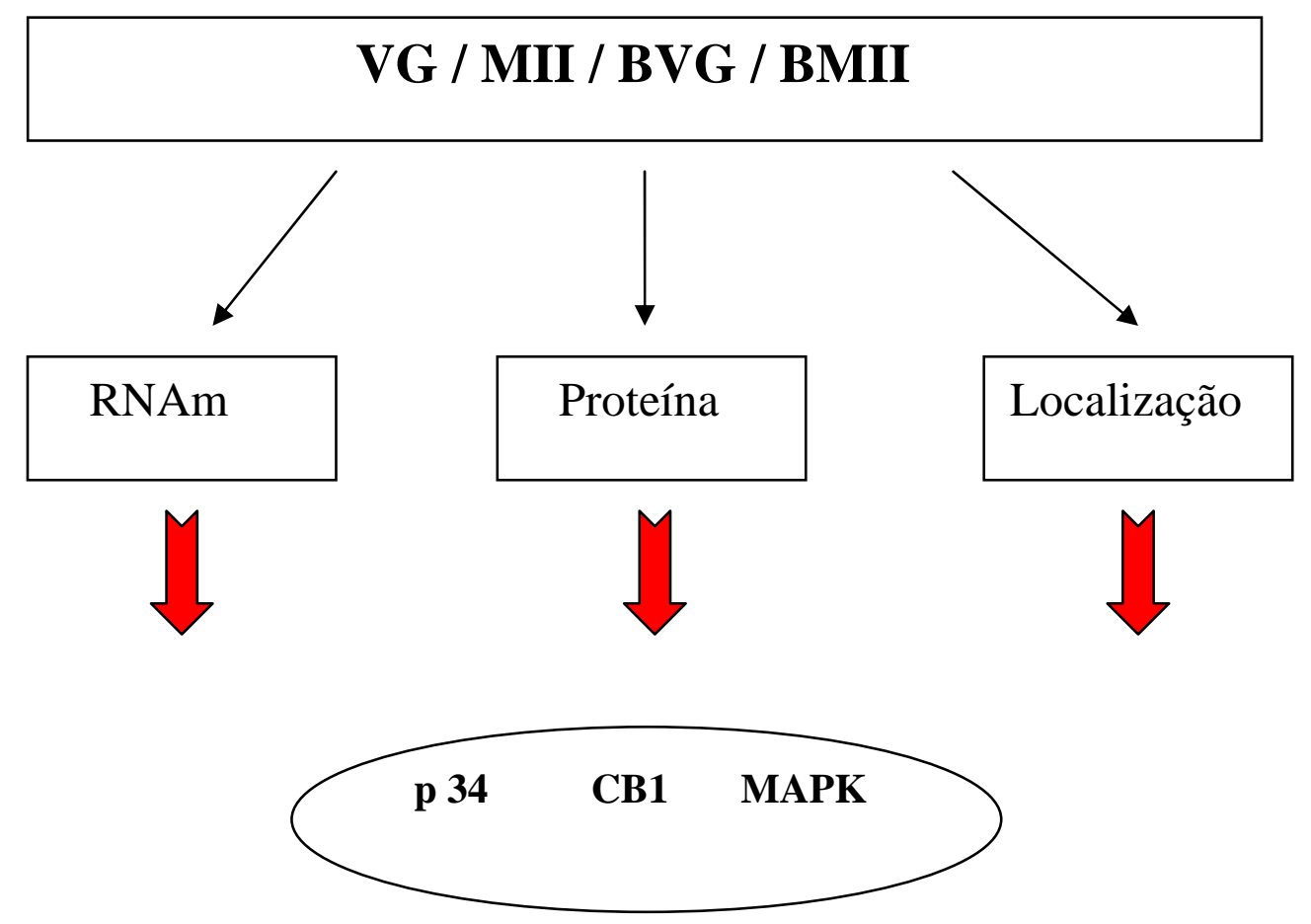

\section{Atividade do MPF e MAPK}
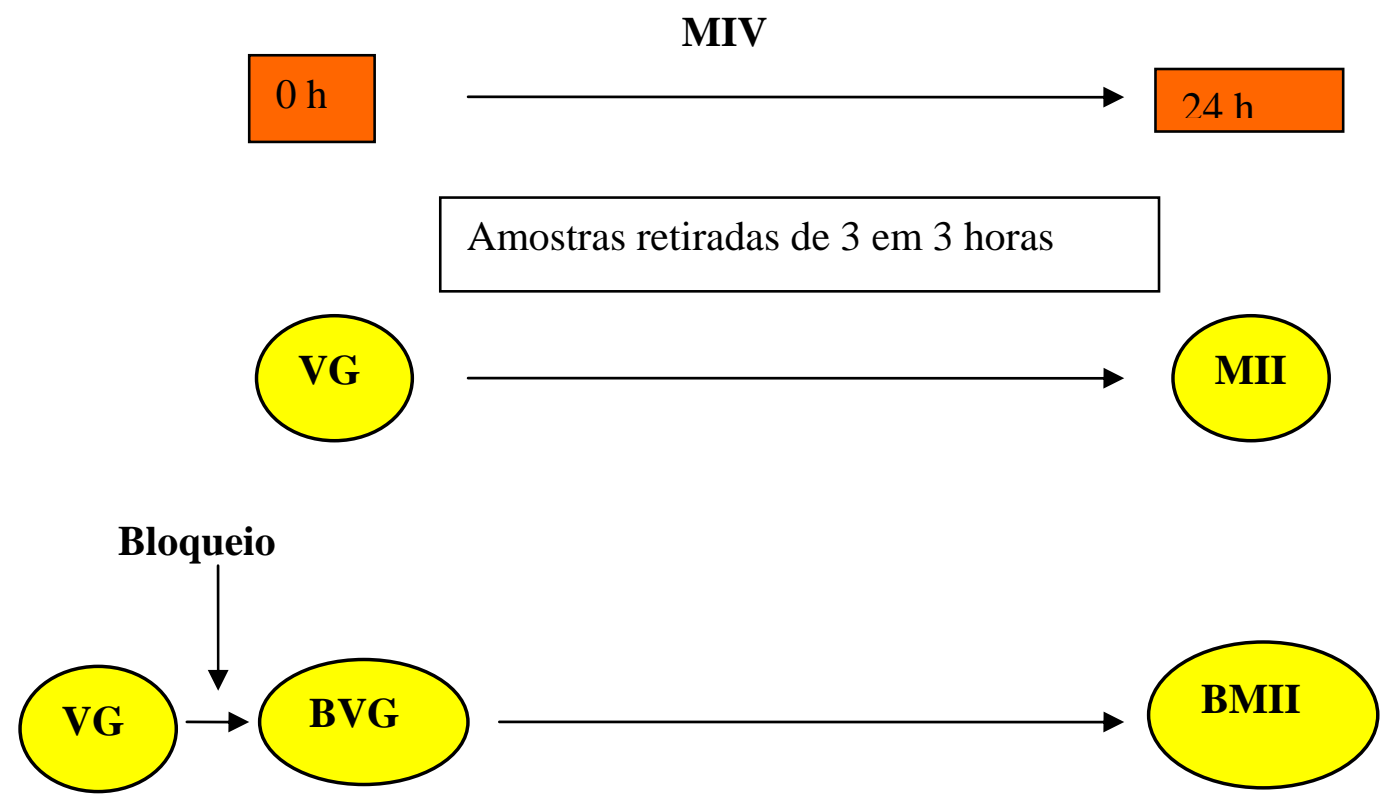

Figura 2 - Diagrama representativo das avaliações experimentais. 


\subsection{Analise Estatística}

Os dados foram analisados por ANOVA. Para os dados relativos ao PCR e western blotting foi utilizado o software o Bio Estat, versão 4.0 (AYRES et al., 2005) e o teste de Tukey para comparar os tratamentos. Para atividade de MPF e MAPK foi usado o pacote estatístico Statistical Analysis System, versão 9.1.3 (SAS, 1995) utilizando o método dos quadrados mínimos (PROC GLM). Foi considerado um nível de significância de 5\% em todas as análises. 


\section{RESULTADOS}

\subsection{Experimento 1 - Efeito do bloqueio meiótico na expressão de RNAm para p34, ciclina B1 e MAPK}

$\mathrm{Na}$ Figura 3 encontra-se a representação gráfica das expressões relativas dos transcritos avaliados pela PCR em tempo real e na Figura 4 uma imagem digitalizada representativa dos fragmentos observados no gel de agarose $2 \%$.

Os transcritos para p34 ${ }^{\mathrm{cdc} 2}$, ciclina B1 e MAPK foram detectados em todas as categorias de oócitos. Ao comparar os oócitos imaturos controles (VG) e os imaturos bloqueados (BVG), observou-se que os transcritos mantiveramse estáveis, não havendo efeito do bloqueio na expressão de nenhum dos genes avaliados $(P>0,05)$, enquanto os oócitos foram mantidos imaturos in vitro.

Quando os oócitos controles (não bloqueados) foram maturados in vitro, as expressões relativas de $\mathrm{p} 34^{\mathrm{cdc} 2}$ e de MAPK foram reduzidas $(P<0,05)$ enquanto que a de ciclina B1 manteve-se estável $(P>0,05)$. O mesmo padrão foi observado após a maturação in vitro dos oócitos bloqueados. Não houve diferença na expressão de nenhum dos genes entre os oócitos maturados bloqueados ou não $(P>0,05)$, indicando que após a maturação também não houve efeito do bloqueio da meiose pré-maturação. 

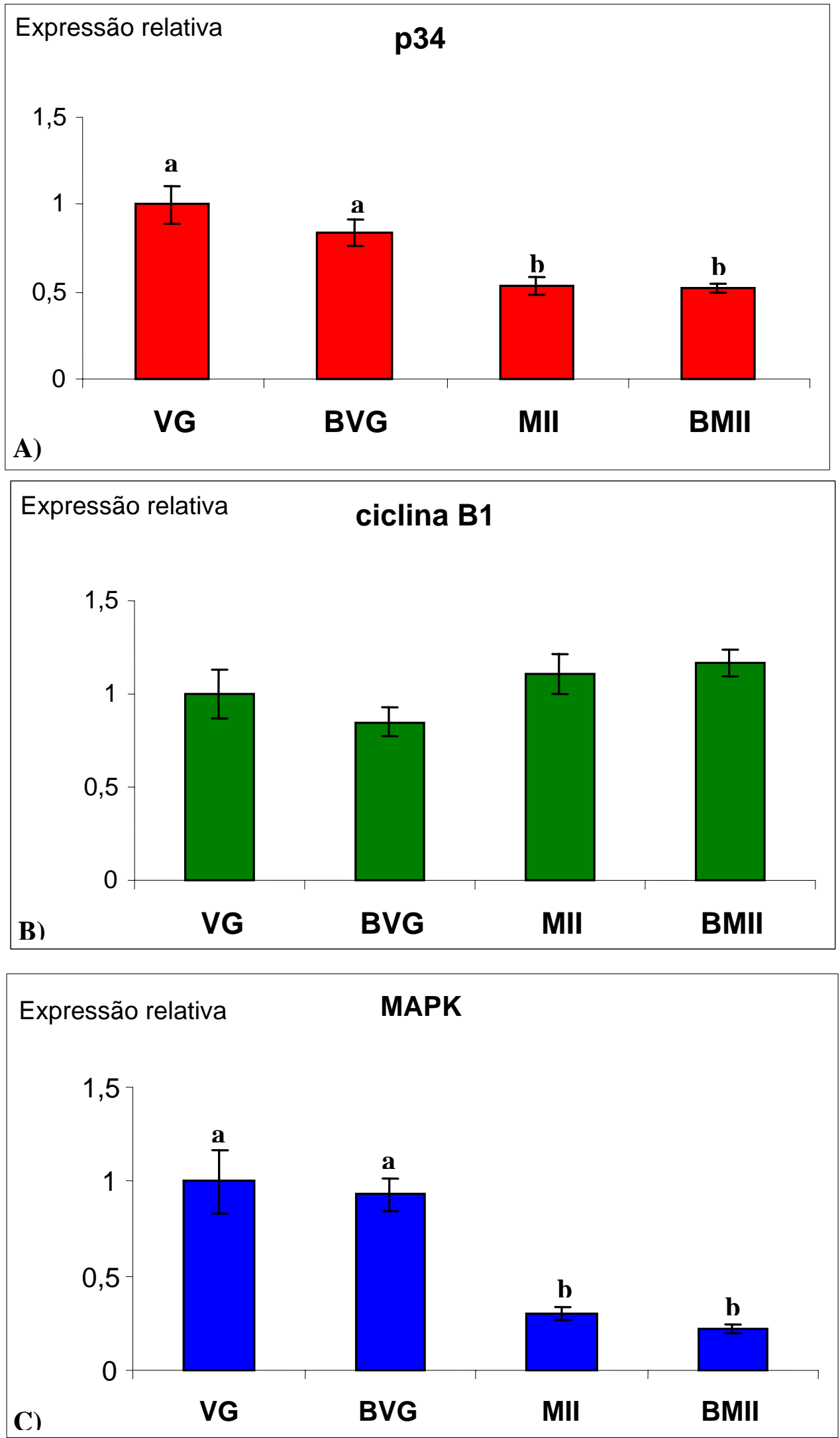

Figura 3 - Abundância relativa dos transcritos para $\mathrm{p} 34^{\mathrm{cdc} 2}$ (A), ciclina B1 (B) e MAPK (C) antes e após a maturação in vitro de oócitos bovinos submetidos ou não ao bloqueio prévio da meiose. VG, oócitos imaturos controles recém-aspirados dos folículos ovarianos; BVG, oócitos imaturos após o bloqueio meiótico in vitro; MII, oócitos controles maturados in vitro 
(metáfase II); BMII, oócitos maturados in vitro após o bloqueio meiótico. Letras diferentes indicam diferença estatística entre os grupos $(P<0.05)$.

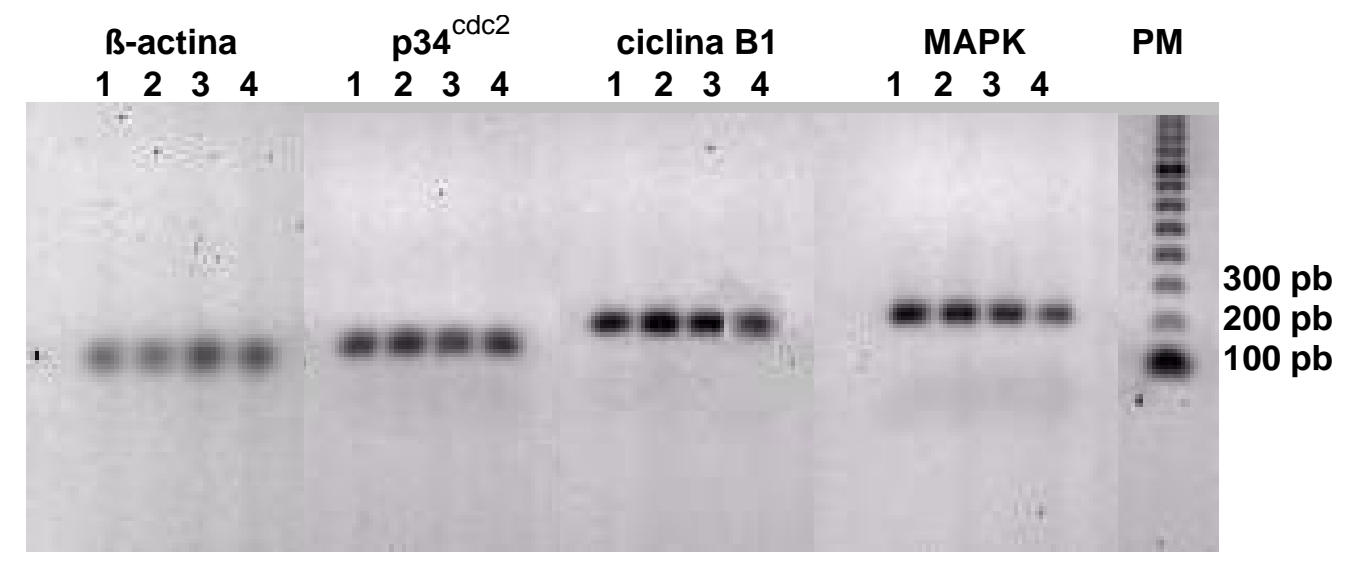

Figura 4 - Imagem digitalizada representativa das bandas observadas em gel de agarose dos fragmentos amplificados por RT-PCR dos genes avaliados para os diferentes grupos. Oócitos imaturos (1), oócitos maturados (2), oócitos imaturos após o bloqueio meiótico (3) e oócitos maturados após o bloqueio meiótico (4). Marcador de peso molecular (PM) em pares de base (pb).

\subsection{Experimento 2 - Efeito do bloqueio meiótico na expressão das proteínas p34, ciclina B1 e MAPK}

A p34 ${ }^{\text {cdc2 }}$ foi detectada em todos os oócitos avaliados, ou seja, imaturos controles e bloqueados, bem como maturados controle e bloqueados (Figura 5). A expressão dessas proteínas manteve-se estável em todos os grupos avaliados $(P>0,05)$, não sendo afetadas, portanto, pela maturação in vitro ou pelo bloqueio da meiose. 


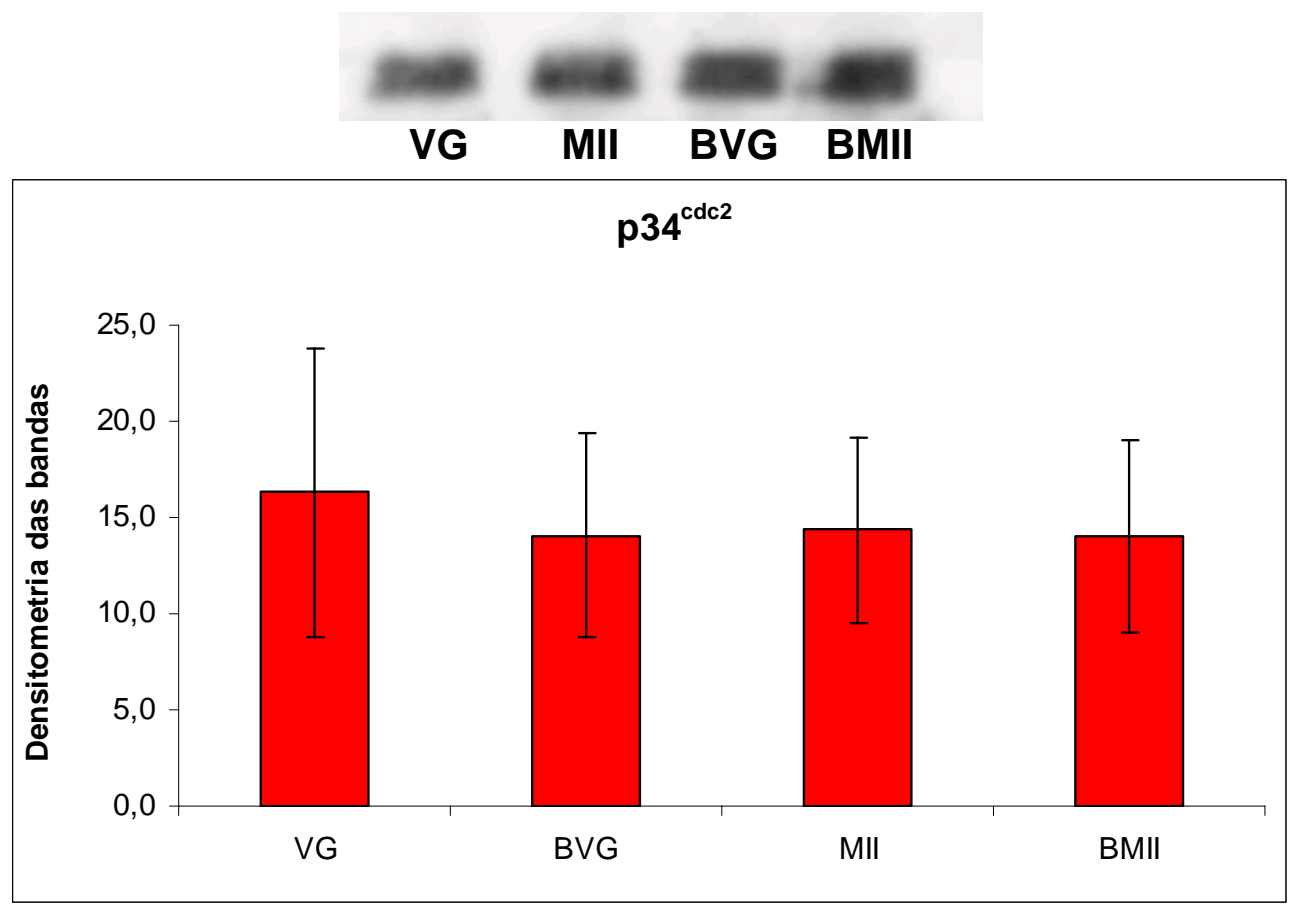

Figura 5 - Detecção da proteína p34 ${ }^{\text {cdc2 }}$ antes e após a maturação in vitro de oócitos bovinos submetidos ou não ao bloqueio prévio da meiose. Oócitos imaturos controle (VG) e bloqueados (BVG) e maturados controle (MII) e maturados bloqueados (BMII). Na parte superior uma imagem digitalizada representativa das membranas em que foi feita a detecção da proteína p34 ${ }^{\text {cdc2 }}$. No gráfico a densitometria das bandas observadas nas membranas. Não houve diferença entre os grupos $(P>0,05)$. Resultados de três repetições.

A expressão da ciclina B1 em nível de proteína, também foi detectada em todas as categorias de oócitos avaliadas (Figura 6). Observou-se que oócitos imaturos, tanto controles (VG) quanto bloqueados (BVG) a proteína não foi detectada. O bloqueio da meiose não promoveu a expressão dessa proteína, mantendo o mesmo padrão de oócitos imaturos recém-aspirados do folículo.

Após a maturação in vitro, os oócitos maturados apresentaram a proteína da ciclina B1 indicando que durante a maturação a mensagem foi traduzida. Os oócitos que foram bloqueados antes da maturação também apresentaram a ciclina B1 em níveis elevados assim como observados nos apenas maturados. O bloqueio não interferiu na capacidade dos oócitos em traduzirem o RNA mensageiro e sintetizar a proteína ciclina B1 durante a maturação. 


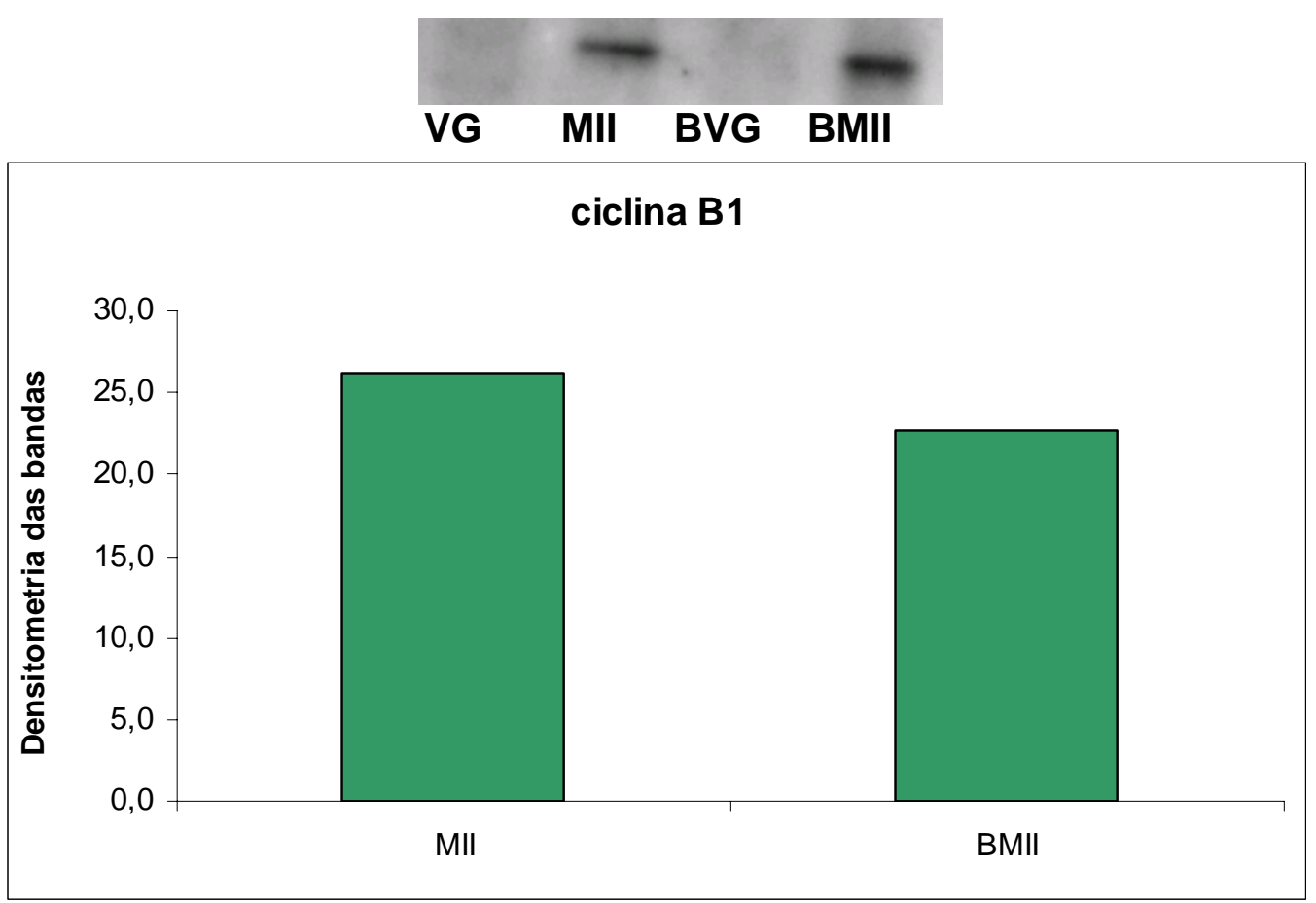

Figura 6 - Detecção da proteína ciclina B1 antes e após a maturação in vitro de oócitos bovinos submetidos ou não ao bloqueio prévio da meiose. Oócitos imaturos controle (VG) e bloqueados (BVG) e maturados controle (MII) e maturados bloqueados (BMII). Na parte superior uma imagem digitalizada representativa das membranas em que foi feita a detecção da proteína ciclina B1. No gráfico a densitometria das bandas observadas nas membranas. A ciclina B1 foi detectada apenas nos grupos submetidos à maturação in vitro (MII e BMII). Oócitos imaturos (VG e BVG) não apresentaram a proteína. Resultados de três repetições.

A MAPK, representada pelas proteínas p44 e p42, foi detectada em oócitos imaturos e maturados, tanto controles quanto bloqueados (Figura 7). Não houve diferenças na expressão dessas proteínas em nenhuma das categorias de oócitos avaliadas $(P>0,05)$. A proteína foi estável ao longo da maturação e não foi afetada pelo bloqueio meiótico.

Pode-se inferir, a partir dos dados obtidos, que o bloqueio da meiose nas condições estudadas não interferiu na capacidade de expressão adequada das proteínas avaliadas. No caso da ciclina B1, que estava ausente em oócitos imaturos, o bloqueio não permitiu que houvesse síntese da proteína, mas durante o período de cultivo de maturação in vitro o bloqueio não interferiu na tradução durante a maturação. 


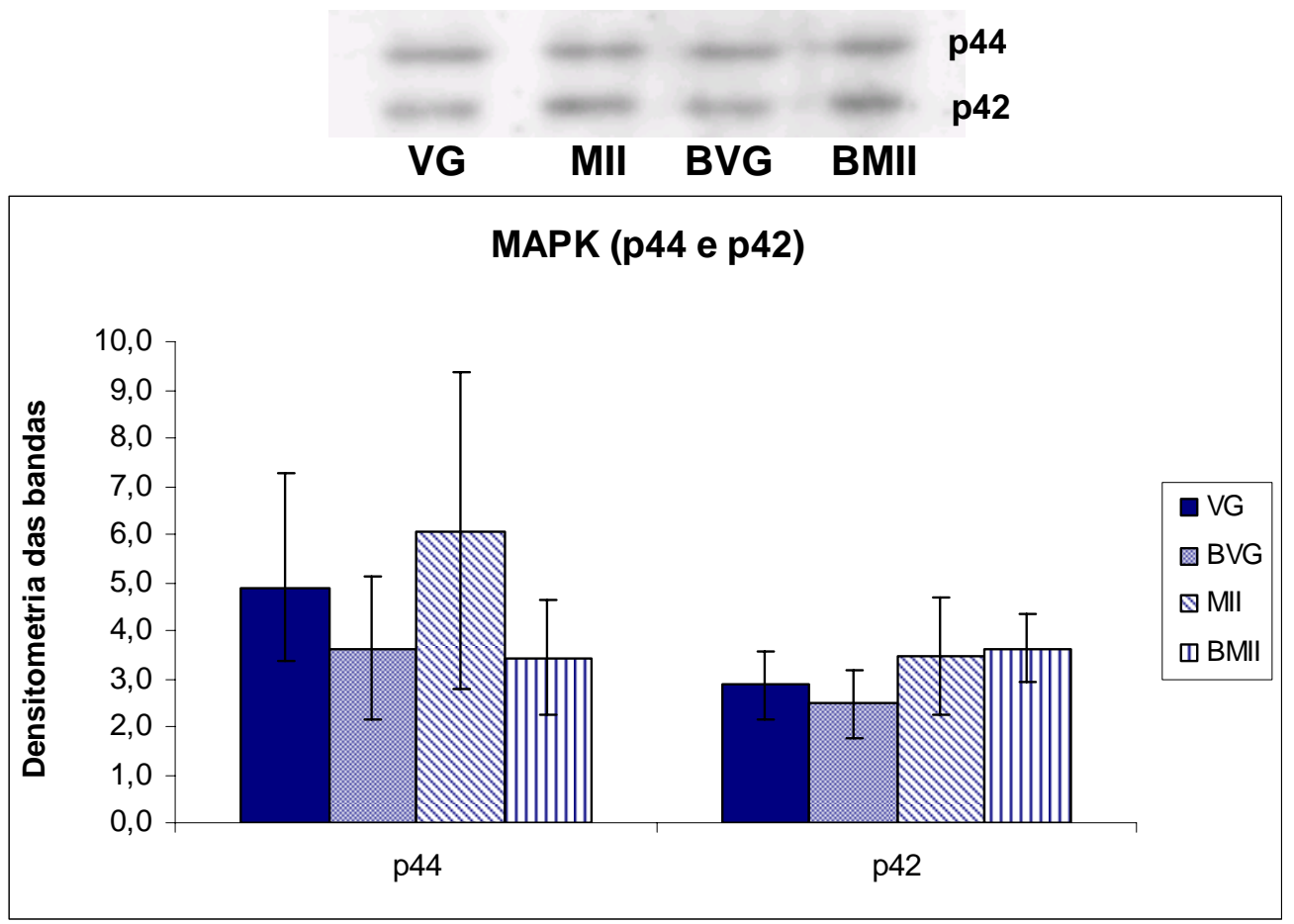

Figura 7 - Detecção da proteína MAPK (p44 e p42) antes e após a maturação in vitro de oócitos bovinos submetidos ou não ao bloqueio prévio da meiose. Oócitos imaturos controle (VG) e bloqueados (BVG) e maturados controle (MII) e maturados bloqueados (BMII). Na parte superior uma imagem digitalizada representativa das membranas em que foi feita a detecção da proteína $\mathrm{p} 34^{\mathrm{cdc} 2}$. No gráfico a densitometria das bandas observadas nas membranas. Não houve diferença entre os grupos $(P>0,05)$. Resultados de três repetições.

\subsection{Experimento 3 - Efeito do bloqueio meiótico na atividade de MPF e MAPK}

Nesse experimento observou-se que a atividade de MPF no grupo controle (C, Figuras 8 e 10) encontrava-se em níveis basais entre 0-6 h. Após 6 h de maturação, começou a haver um ligeiro aumento na atividade desse fator, que continuou aumentando progressivamente com um pico às $9 \mathrm{~h}$. Houve uma queda transitória entre 12 e 21 h de MIV e depois um segundo pico às 24 h. .

No grupo bloqueado antes da maturação (B10, Figuras 8 e 10) observou-se que já havia alguma atividade presente às $0 \mathrm{~h}$, ou seja, no final do bloqueio. Às $6 \mathrm{~h}$ de maturação começou a haver aumento de atividade com um pico às $9 \mathrm{~h}$. A partir daí, houve um declínio transtiório com um segundo pico às $21 \mathrm{~h}$. Às $24 \mathrm{~h}$ houve um declínio de atividade. 
Atividade de MPF

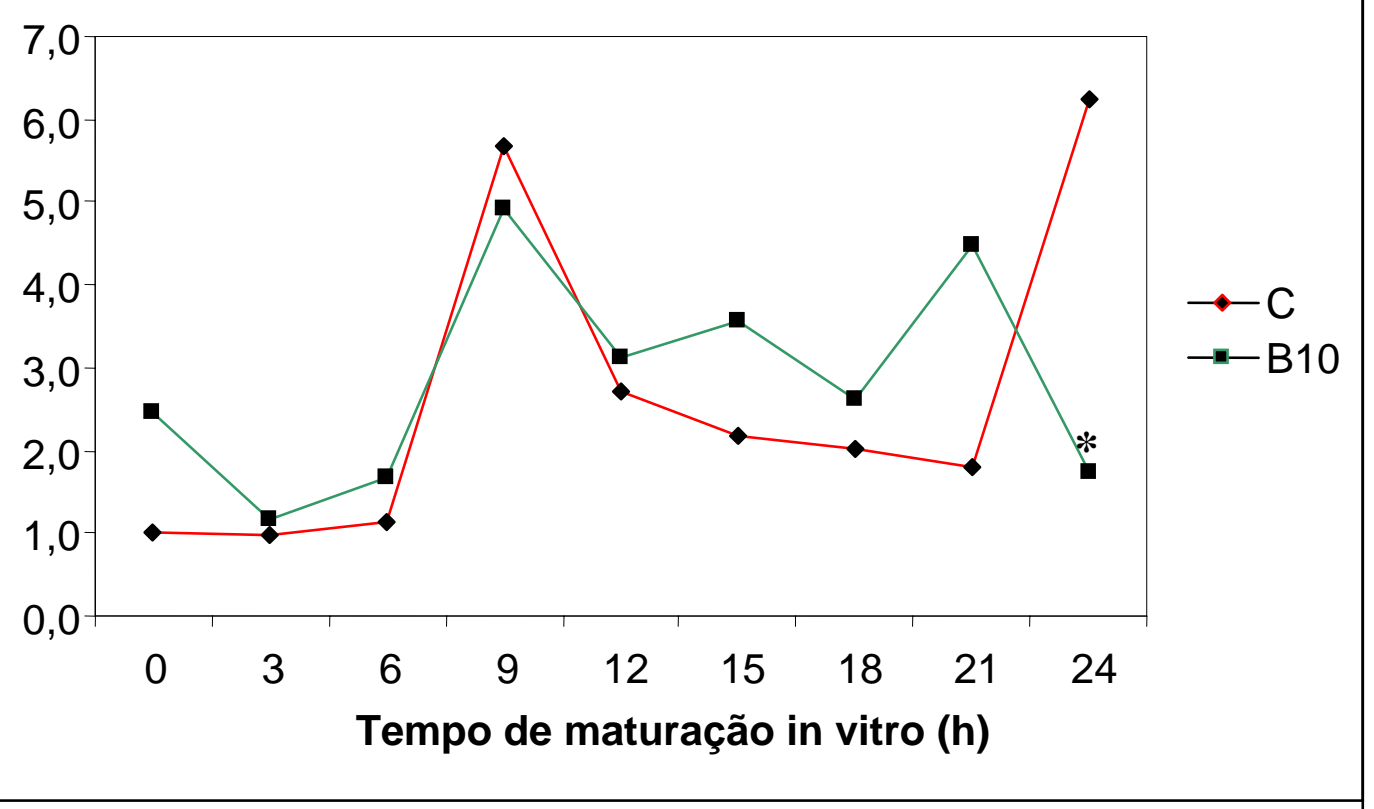

Figura 8 - Atividade de MPF ao longo da maturação in vitro de oócitos submetidos ao bloqueio meiótico (B10) ou apenas maturados in vitro (C). A atividade determinada no oócito imaturo controle $(0 \mathrm{~h})$ foi considerada como unidade arbitrária $(1,0)$ e as demais atividades determinadas como um múltiplo dessa unidade. *Diferença estatística com o controle $(P<0,05)$. Resultados de três repetições.

Comparando-se o padrão de atividade entre os dois grupos, observa-se que foi similar na maior parte do tempo, mas com pequenas diferenças. No inicio da maturação $(0 \mathrm{~h})$, que para B10 correspondeu ao final do bloqueio, havia um pouco de atividade presente, porém, não foi significativa a diferença em relação ao controle $(P>0,05)$. Depois, ao longo da maturação, 0 comportamento dos dois grupos também foi similar $(P>0,05)$. B10 teve um segundo pico às $21 \mathrm{~h}$, mas novamente não foi diferente do controle $(P>0,05)$. Só houve diferença às $24 \mathrm{~h}$, quando B10 teve atividade de MPF já em queda, sendo inferior ao controle $(P<0,05)$.

Em relação à atividade de MAPK (Figuras 9 e 10), o grupo controle manteve níveis basais entre 0-6 h de MIV, começando a aumentar progressivamente de atividade até um máximo em torno de $12 \mathrm{~h}$. A partir daí até $24 \mathrm{~h}$, a atividade de MAPK manteve-se elevada.

No grupo tratado (B10), a atividade de MAPK (Figuras 9 e 10) também exibiu comportamento similar, com níveis mais baixos entre 0-6 h, aumentando até $12 \mathrm{~h}$ e depois mantendo a atividade elevada até as $24 \mathrm{~h}$. 


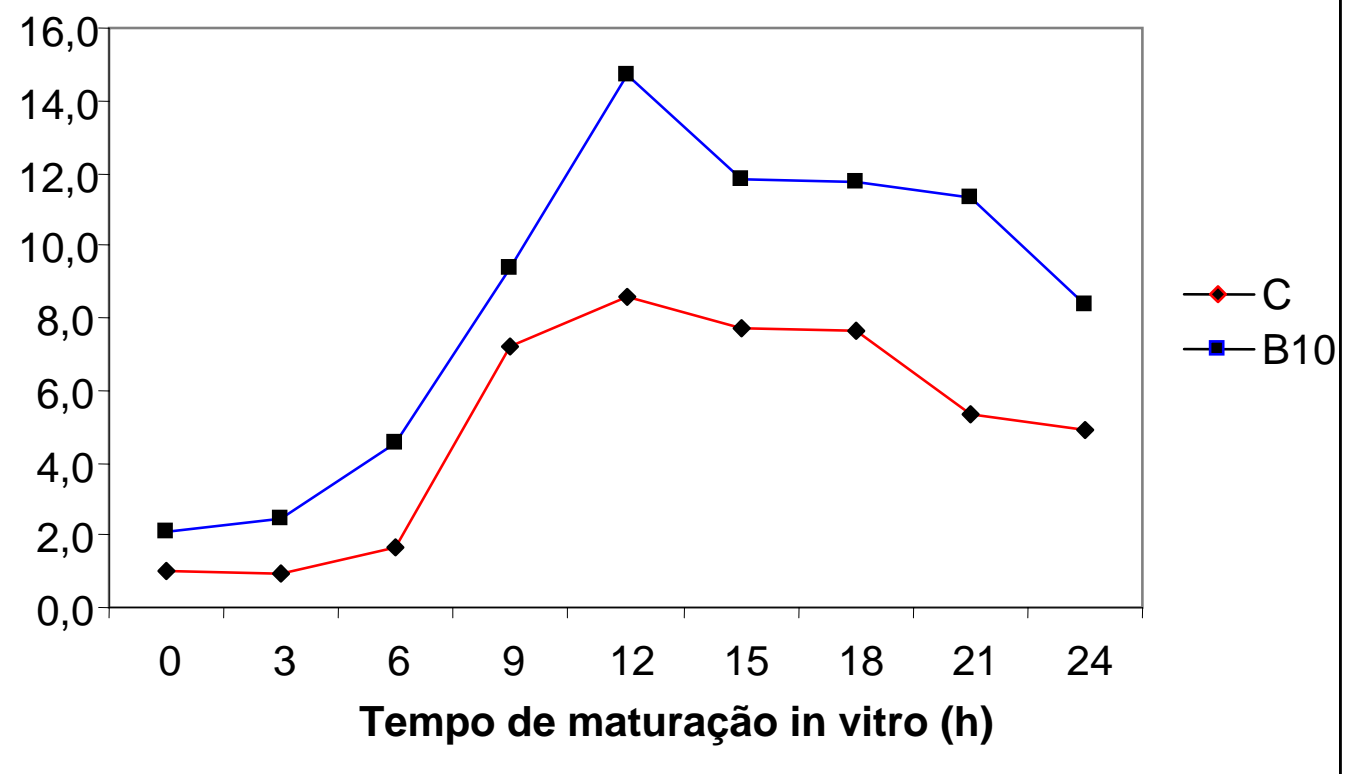

Figura 9 - Atividade de MAPK ao longo da maturação in vitro de oócitos submetidos ao bloqueio meiótico (B10) ou apenas maturados in vitro (C). A atividade determinada no oócito imaturo controle $(0 \mathrm{~h})$ foi considerada como unidade arbitrária $(1,0)$ e as demais atividades determinadas como um múltiplo dessa unidade. Não houve diferença entre os grupos $(P>0,05)$. Resultados de três repetições.

Embora o grupo tratado tenha exibido atividade de MAPK ligeiramente superior ao controle ao longo do tempo, os grupos não deferiram entre si em nenhum dos horários $(\mathrm{P}<0,05)$.

Os perfis de atividade de MPF e MAPK foram similares aos relatados anteriormente para oócitos não bloqueados antes da maturação (KUBELKA et al., 2000; WU et al., 1997). A ativação de ambas ocorreu próximo ao período estimado da quebra da VG ( 9 h). Posteriormente, a atividade da MAPK manteve-se até o final da MIV (24 h), enquanto o MPF apresentou um ligeiro declínio em torno de $12 \mathrm{~h}$, seguido de recuperação com um segundo pico às 24 h. 
C \{

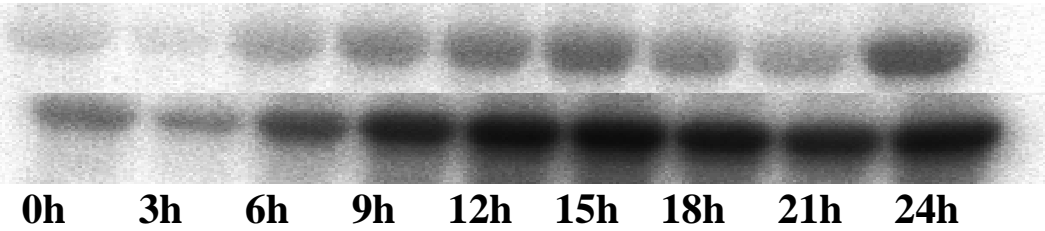

H1

MBP

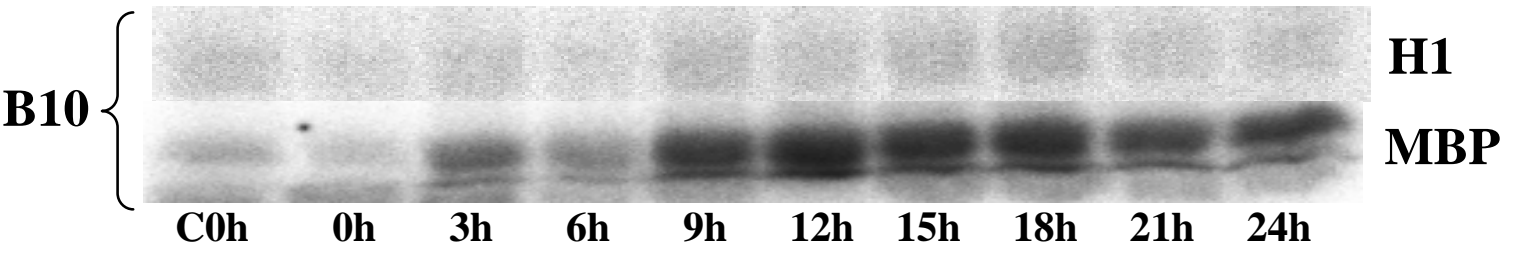

Figura 10 - Imagem digitalizada representativa das bandas observadas a cada três horas ao longo da maturação in vitro (0 às $24 \mathrm{~h}$ ) do grupo bloqueado com $10 \mu \mathrm{M}$ de butirolactona I por 24 horas antes da maturação (B10). HI, histona H1 fosforilada pelo MPF; MPB, proteína básica de mielina fosforilada pela MAPK.

\subsection{Experimento 4 - Efeito do bloqueio meiótico na localização subcelular das proteínas $\mathrm{p} 34^{\mathrm{cdc2}}$, ciclina B1 e MAPK}

Nos oócitos imaturos recém-aspirados dos folículos (controles) ou bloqueados antes da maturação a proteína p34 ${ }^{\text {cdc2 }}$ foi observada distribuída em todo o citoplasma apresentando uma fluorescência intensa. Essa proteína apresentou-se como pequenos pontos e com uma marcação mais proeminente numa área coincidente com a vesícula germinativa. Após a maturação, a p34 ${ }^{\text {cdc2 }}$ continuou em todo o citoplasma, porém, sem marcação específica na ausência do núcleo (Figura 11).

A proteína ciclina B1 também foi detectada por todo o citoplasma com um aspecto granular, sem grandes variações entre oócitos imaturos ou maturados e bloqueados ou não (Figura 12).

A MAPK apresentou uma marcação leve em todo o citoplasma com finas granulações e também não exibiu variações na sua distribuição em relação ao estádio de maturação ou se bloqueado ou não (Figura 13). Na Figura 14 podese observar oócitos controles da técnica em que o anticorpo primário foi omitido da reação. 


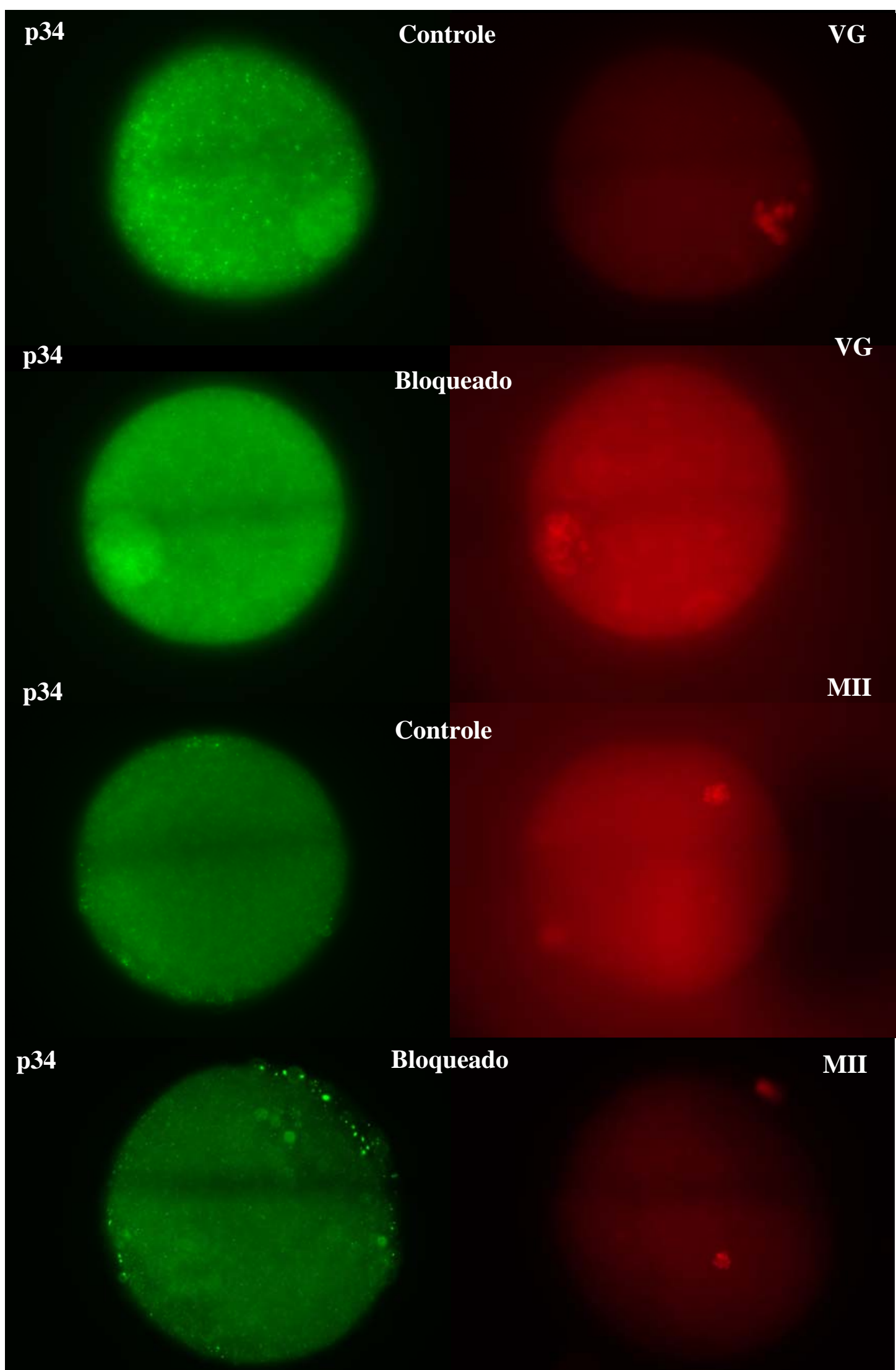

Figura 11 - Imagens representativas de oócitos bovinos marcados para p34 ${ }^{\text {cdc2 }}$. A proteína p34 ${ }^{\text {cdc2 }}$ aparece corada com FITC (verde) e o DNA com iodeto de propídio (vermelho). Controle, oócito não submetido ao bloqueio meiótico; Bloqueado, oócito submetido ao bloqueio da meiose por 24 h; VG, oócito imaturo em vesícula germinativa recém-aspirado do folículo; MII, oócito maturado in vitro em metáfase II. Aumento 400X. 


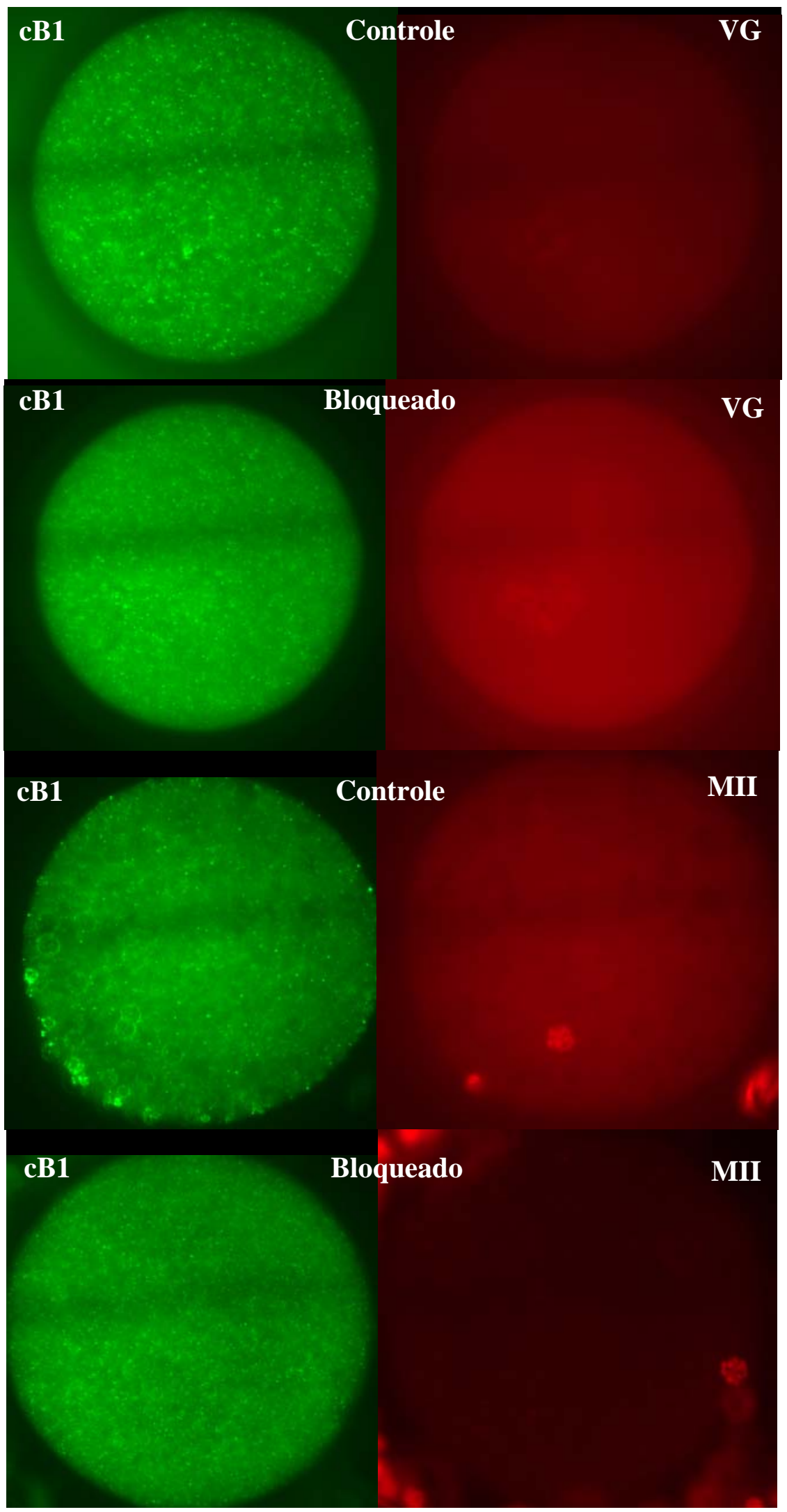

Figura 12 - Imagens representativas de oócitos bovinos marcados para ciclina B1 (cB1). A proteína ciclina B1 aparece corada com FITC (verde) e o DNA com iodeto de propídio (vermelho). Controle, oócito não submetido ao bloqueio meiótico; Bloqueado, oócito submetido ao bloqueio da meiose por 24 h; VG, oócitos imaturo em vesícula germinativa recém-aspirado do folículo; MII, oócito maturado in vitro em metáfase II. Aumento 400X. 


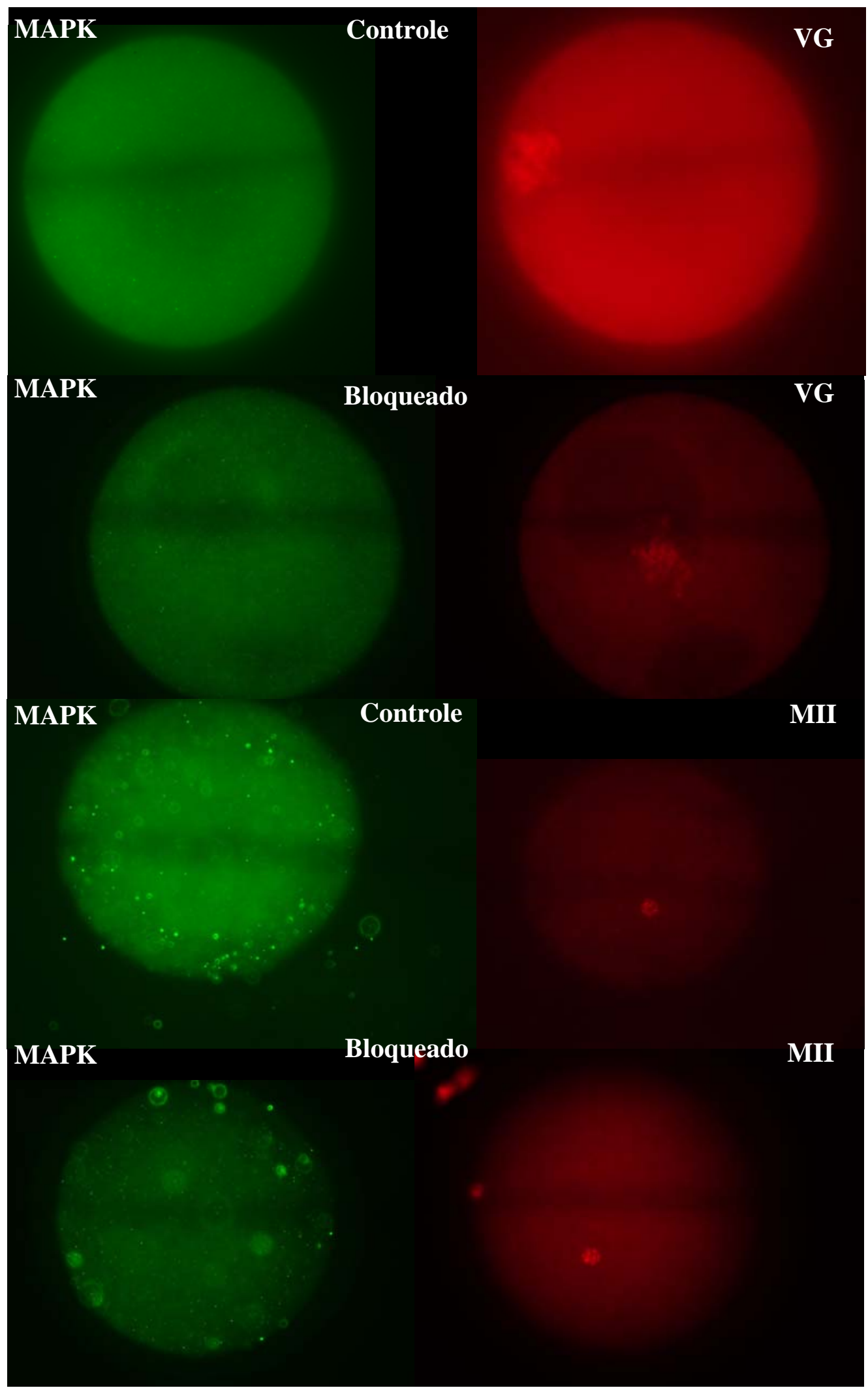

Figura 13 - Imagens representativas de oócitos bovinos marcados para MAPK. A proteína MAPK aparece corada com FITC (verde) e o DNA com iodeto de propídio (vermelho). Controle, oócito não submetido ao bloqueio meióíico; Bloqueado, oócito submetido ao bloqueio da meiose por 24 h; VG, oócitos imaturo em vesícula germinativa recém-aspirado do folículo; MII, oócito maturado in vitro em metáfase II. Aumento 400X. 

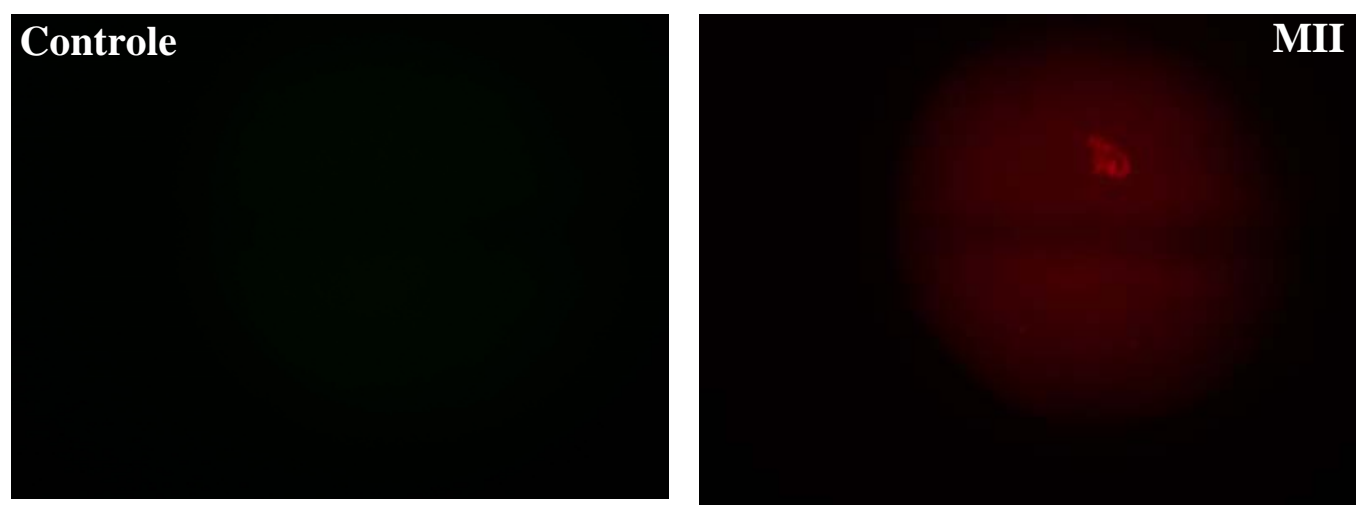

Figura 14 - Oócito bovino submetido à imunofluorescência sem utilização do anticorpo primário como controle da reação. Controle, controle da reação com ausência de fluorescência; MII, oócito maturado in vitro em metáfase II. Aumento 400X. 


\section{DISCUSSÃo}

A detecção de transcritos de p34 $4^{\text {cdc2 }}$ nos oócitos imaturos está de acordo com observações anteriores. A p34 $4^{\mathrm{cdc} 2}$ é a unidade catalítica do MPF, um dos principais fatores envolvidos no controle da meiose (JONES et al., 2004). Esses transcritos são acumulados com o crescimento do oócito e seriam importantes na aquisição de competência do oócito, embora tenha sido observado que oócitos de camundongos competentes e incompetentes já apresentem esses transcritos, o que mudaria em relação à competência seria a eficiência na sua tradução e a estabilidade da mensagem (MITRA; SCHULTZ et al., 1996).

Vigneron et al. (2004a), relataram que oócitos bovinos em estádio de vesícula germinativa já apresentam os transcritos para os componentes do MPF e para a MAPK e que não houve diferença detectável em relação ao diâmetro dos folículos (ROBERT et al., 2002). De forma similar, Anguita et al. (2007) observaram que em oócitos de caprinos pré-púberes, o RNA de p34 ${ }^{\text {cdc2 }}$ também está presente e não variou em relação ao diâmetro dos mesmos. Sabe-se que os diâmetros do oócito e do folículo têm influência na competência dos mesmos (HYTTEL et al., 1997; 2001; LONERGAN et al., 1994). Essas observações reforçam a hipótese de que a competência seja relacionada não só com o acúmulo de transcritos, mas também com o controle e a eficiência na sua utilização.

Quando os oócitos foram maturados in vitro, observou-se uma redução nos transcritos para p34 ${ }^{\text {cdc2 }}$, concordando com observações anteriores (VIGNERON et al., 2004a). Esses autores, no entanto, sugerem que essa redução seria devida às condições sub-ótimas de cultivo, visto que in vivo, o RNAm de p34 ${ }^{\mathrm{cdc} 2}$ teve um aumento. Isso ocorreu possivelmente, porque, in vivo, haveria um maior acúmulo de RNA ao final da foliculogênese e até um pouco antes da quebra da VG, ou ainda, por diferenças na regulação da poliadenilação do RNAm. A poliadenilação é um dos mecanismos de controle da tradução de mensagens nos oócitos (TOMEK et al., 2002; BETTEGOWDA; 
SMITH, 2007) e a expressão de RNAm pode ser afetada pelas condições de cultivo (BREVINI et al., 2007).

Em caprinos pré-púberes, a et al. (2007) também relataram uma redução no RNA de p34 ${ }^{\text {cdc2 }}$ e que foi influenciada pelo diâmetro do oócito. De acordo com esses autores, oócitos de diâmetros maiores, mas que ainda não atingiram o crescimento completo, acumulariam o RNA de p34 ${ }^{\text {cdc2 }}$ até esse período e ao final do crescimento oocitário, haveria redução devido à síntese protéica. Não se pode excluir, porém, que também que tenha havido degradação, visto que mensagens relacionadas ao controle do ciclo celular estão entre as mais degradas ao longo do processo de maturação (SU et al., 2006).

Nas nossas condições de estudo, no entanto, não é possível determinar qual evento estaria promovendo a redução nos transcritos de $\mathrm{p} 34^{\mathrm{cdc} 2}$, se a tradução e/ou degradação. Quando os oócitos foram bloqueados em vesícula germinativa com butirolactona I, o RNAm de p34 ${ }^{\text {cdc2 }}$ manteve-se em níveis similares aos dos oócitos imaturos recém-aspirados do folículo. Vigneron et al. (2004a), utilizando um inibidor de proteínas cinases dependentes de ciclinas similar à butirolactona I (roscovitina) também relataram observações semelhantes. O bloqueio da meiose com drogas que inibem o MPF, de alguma forma impede a tradução e/ou degradação de transcritos que ocorre com a retomada da meiose. Se a meiose não reinicia, também não ocorre a redução de transcritos de $\mathrm{p} 34^{\mathrm{cdc} 2}$.

Foi observado que a roscovitina inibiu quase toda a reprogramação na síntese e fosforilação de proteínas que ocorre com a maturação (VIGNERON et al., 2004a). A BLI é capaz de inibir a fosforilação do fator elF4E envolvido no recrutamento de RNm para os ribossomos, inibindo, portanto, a síntese protéica (TOMEK et al., 2002). O bloqueio dessas atividades celulares, porém, é reversível, visto que após a maturação de oócitos bloqueados observa-se o mesmo declínio do RNAm de p34 ${ }^{\mathrm{cdc} 2}$ observado na maturação de oócitos não bloqueados, assim como foi observado por Vigneron et al., (2004a). Os resultados do presente estudo, portanto, sugerem que o padrão de RNAm para p34 ${ }^{\text {cdc2 }}$ não foi afetado pelo tratamento do bloqueio da meiose com butirolactona I, observando-se apenas o efeito da maturação in vitro. 
Quando foi avaliada a expressão relativa de ciclina B1, observou-se que a mesma, assim como a p34 ${ }^{\mathrm{cdc} 2}$, estava presente nos oócitos imaturos, corroborando com observações de estudos anteriores. Mitra e Schultz (1996), observaram que assim como para o RNAm de p34 ${ }^{\text {cdc2 }}$, transcritos de ciclina B1 também estavam presentes em oócitos imaturos de camundongos e que tais transcritos era acumulados ao longo do crescimentos oocitário. Embora fosse observado um acúmulo de RNAm de ciclina B1 a concentração foi similar entre oócitos incompetentes e competentes.

Hue et al. (1997) também detectaram RNAm de cinclina B1 em oócitos competentes e incompententes, mas que a maior síntese de transcritos ocorria ao fina do crescimento do oócito. Em bovinos, Robert et al. (2002) detectaram o RNAm de ciclina B1 desde a vida fetal e comparando oócitos oriundos de folículos de folículos de diâmetros diferentes (> $2 \mathrm{~mm}$ ) não observou diferenças. A ciclina B1 é estocada em grande quantidade no oócito na forma de RNAm (ROBERT et al., 2002).

Quando os oócitos foram maturados in vitro, ao contrário do observado para p34 $4^{\text {cdc2 }}$, os transcritos de ciclina B1 mantiveram-se estáveis. Essas observações concordam com relatos de outros estudos (LEQUARRE et al., 2004; TRAVERSO et al., 2005; TREMBLAY et al., 2005) em que os transcritos de ciclina B1 mantiveram-se estáveis após a maturação enquanto outros foram reduzidos. Racedo et al. (2008) também observaram que durante a maturação in vitro há transcritos que se mantém estáveis ou que são reduzidos, possivelmente relacionados à degradação diferencial e seletiva (SU et al., 2006).

No entanto, assim como observado para a p34 $4^{\text {cdc2 }}$, Vigneron et al. (2004a) também relataram um aumento nos transcritos de ciclina B1 quando os oócitos foram maturados in vivo. A mesma observação foi feita por Lonergan et al. (2003b) quando os oócitos foram capacitados e maturados in vitro. Esses autores sugeriram que haveria um acúmulo de transcritos durante a maturação in vivo e que isso seria relacionado à qualidade intrínseca do oócito. Quando os oócitos foram capacitados in vivo, mas maturados in vitro, esse efeito não foi mais observado, sendo a expressão similar à de oócitos maturados in vitro sem passar pela capacitação. 
Gomez et al. (2004), por outro lado observaram um aumento na abundância relativa de cinclina B1 após a maturação in vitro. As causas dessa diferença poderiam ser relacionadas a diferenças nas condições de cultivo. Como mencionado anteriormente a expressão de RNAm pode ser afetada pelas condições de cultivo in vitro (BREVINI et al., 2007b).

A ciclina B tem sido relacionada ao controle da retomada da meiose, sendo poliadenilada durante a primeira metade da maturação (TRAVERSO et al., 2005) indicando que entra em processo de tradução (LEQUARRE et al., 2004; TREMBLAY et al., 2005). Embora a ciclina esteja sendo traduzida, seus transcritos não seriam reduzidos visto que quando o oócito atinge o estádio de metáfase II (maturado), eles devem estar presentes para garantir que a ciclina B seja traduzida de forma a manter a atividade de MPF em altos níveis, responsável pela manutenção do oócito bloqueado em MIl até a fecundação (JONES et al., 2004).

O cultivo de oócitos imaturos em meio contendo butirolactona I também não afetou a expressão da ciclina B1. Vigneron et al. (2004a) também fizeram observação similar, enquanto Gómez et al. (2004) observaram um aumento nos transcritos durante o bloqueio. Há poucos estudos acerca do efeito do bloqueio meiótico com inibidores de CDK sobre o RNAm de p34 ${ }^{\text {cdc2 }}$ e ciclina B1. No entanto, sabe-se que o bloqueio meiótico pode afetar a expressão gênica, aumentando ou reduzindo transcritos, dependendo do gene avaliado e do inibidor utilizado (WRENZYCKI et al., 2003). Esses autores relataram que o uso de baixas concentrações de uma mistura de inibidores (butirolactona I e roscovitina) ocasionou variações menores sobre a expressão relativa de RNAm. No presente estudo e no de Vigneron et al. (2004a) foi utilizada a butirolactona I e no de Gómez et al. (2004) foi utilizada a roscovitina, o que poderia ter levado a essa diferença nos resultados.

Após a maturação in vitro dos oócitos bloqueados o comportamento foi similar ao de oócitos não bloqueados, ou seja, a expressão relativa de ciclina B1 manteve-se estável, concordando com as observações de Vigneron et al. (2004a). Gomez et al. (2004), por outro lado, relataram que também nos oócitos bloqueados houve aumento nos transcritos como ocorreu nos controles. Independente de haver aumento ou estabilidade dos transcritos, os 
resultados apresentados indicam que não houve efeito do bloqueio na expressão gênica da ciclina B1 após a maturação.

Em nossas condições de cultivo in vitro, a expressão relativa da ciclina B1 não foi afetada pelo bloqueio meiótico ou pela maturação. Obviamente que extrapolações para a condição in vivo devem ser feitas com cautela, pois como relatado anteriormente, há importantes diferenças na expressão gênica de oócitos maturados in vivo e in vitro (LONERGAN et al., 2003b; VIGNERON et al. 2004a).

Em relação à MAPK observamos que os transcritos estavam presentes em oócitos imaturos. Há apenas o estudo de Robert et al. (2002) que corroboram nossos resultados. Após a maturação houve redução de seus transcritos assim como foi observado para a p34 ${ }^{\text {cdc2 }}$. Não há relatos acerca de sua expressão em nível de RNA após a maturação. Essa proteína parece se enquadrar na categoria de transcritos que são degradados e/ou transcritos ao longo da maturação. Mais provavelmente, tanto a p34 ${ }^{\mathrm{cdc} 2}$ como a MAPK devam estar sendo transcritos, visto que ambas as proteínas foram detectadas em oócitos maturados, como observado nesse estudo (experimento seguinte) como em outros (LEVESQUE; SIRARD, 1996; KUBELKA et al., 2000).

O bloqueio da meiose também não afetou a expressão da MAPK como observado para os outros dois transcritos estudados e após a maturação dos bloqueados, sua expressão declinou como detectado para p34 ${ }^{\text {cdc2 }}$. A MAPK exibiu um comportamento similar ao da $\mathrm{p} 34^{\mathrm{cdc} 2}$ tanto em relação à maturação como em relação bloqueio.

Já foi relatado que o bloqueio meiótico afeta a abundância relativa de RNAs, sendo que o efeito pode ser tanto de aumentar ou diminuir dependendo do transcrito considerado (WRENZYCKI et al., 2003). Além disso, o inibidor utilizado também influencia na expressão. Wrenzycki et al., (2003) observaram, por exemplo, que a associação de baixas concentrações de roscovitina e butirolactona I foi o tratamento que menos influenciou na expressão gênica. Como utilizamos somente a butirolactona I e em concentração mais baixa que a usual, é possível que o tratamento não tenha influenciado negativamente a expressão dos genes em questão. No entanto, não se pode afirmar que outros genes importantes para o ciclo celular e competência oocitária não tenham sido afetados pelo bloqueio da meiose. 
A proteína p34 ${ }^{\text {cdc2 }}$ foi detectada em oócitos imaturos concordando com observações anteriores em bovinos (LEVESQUE; SIRARD, 1997; WU et al., 1997) e outras espécies como camundongos (MITRA; SCHULTZ, 1996) e suínos (CHEN et al., 2000; ENDO et al., 2006; GOTO et al., 2002). Em camundongos foi observado que embora os transcritos de $\mathrm{p} 34^{\mathrm{cdc} 2}$ e ciclina B1 estivessem presentes em oócitos competentes e incompetentes, a proteína de p34 ${ }^{\text {cdc2 }}$ foi observada somente nos competentes (MITRA; SCHULTZ, 1996). O taxa de tradução da p34 $4^{\text {cdc2 }}$ foi maior nos oócitos competentes, embora a estabilidade da proteína tenha sido a mesma, sugerindo que alteração na eficiência da tradução esteja envolvida na competência, ao menos meiótica. Em bovinos foi observado que os oócitos imaturos apresentam RNA e proteína de p34 ${ }^{\text {cdc2 }}$, mas em diferentes propoções. Os oócitos imaturos têm menor quantidade de RNAm de $\mathrm{p} 34^{\mathrm{cdc} 2}$ e maior quantidade de sua proteína e o acúmulo da proteína foi maior em oócitos de folículos maiores (ROBERT et al., 2002).

Quando os oócitos foram maturados a proteína manteve-se estável. Observação semelhante foi feita em oócitos suínos (CHEN et al., 2000), sugerindo que a ativação do MPF depende não somente da presença das suas subunidades (p34 $4^{\text {cdc2 }}$ e ciclina B1), mas de sua associação e de seu estado de fosforilação. Levesque e Sirard (1996) também observaram que a p34 ${ }^{\text {cdc2 }}$ está presente ao longo de toda a maturação de oócitos bovinos ( 0 a $24 \mathrm{~h}$ ), sendo a atividade do MPF mais dependente da síntese de ciclina B1, visto que a p34 ${ }^{\text {cdc2 }}$ já está presente. A p34 ${ }^{\text {cdc2 }}$ não só está presente como parece haver uma síntese adicional no início da maturação (WU et al., 1997). Essa síntese no início da maturação corresponderia ao declínio no RNAm dessa proteína como observado nesse estudo.

Após o bloqueio da meiose a proteína da p34 ${ }^{\mathrm{cdc} 2}$ também se manteve estável, assim como quando os oócitos bloqueados foram também maturados. Não há relatos sobre o efeito do bloqueio meiótico sobre a proteína p34 ${ }^{\mathrm{cdc} 2}$. Apenas num estudo de Jimenez-Macedo et al. (2006) foi descrito que oócitos de cabras pré-púberes já apresentaram a p34 ${ }^{\mathrm{cdc} 2}$ e que esta também se manteve estável após a maturação. Quando a meiose foi bloqueada com roscovitina a proteína se manteve no mesmo nível dos oócitos em VG. A p34 ${ }^{\text {cdc2 }}$ após a maturação de oócitos bloqueados não foi avaliada nesse estudo. 
No entanto, nossa observação indica que o bloqueio não interferiu na expressão da p34 ${ }^{\text {cdc2 }}$ no nível de proteína ao longo de todo o cultivo.

Em relação à ciclina $B 1$, a mesma não foi detectada em oócitos imaturos bloqueados ou não. Em camundongos a ciclina B está presente em oócitos imaturos, mas em quantidades mais baixas nos oócitos competentes (MITRA; SCHULTZ, 1996). Em caprinos, no entanto, os oócitos imaturos apresentam a proteína estocada, mas em maior quantidade nos competentes (HUE et al., 1997). Oócitos suínos também apresentam a ciclina B1 na forma de proteína (CASAS et al., 1999; CHEN et al, 2000), embora haja relatos de que a ciclina B1 não seja observada antes da maturação (ENDO et al., 2006).

Oócitos imaturos bovinos apresentam pouca ou nenhuma proteína de ciclina B1 presente (LEVESQUE; SIRARD, 1996; ROBERT et al, 2002), embora tenham RNA armazenado, como observado nesse estudo e em outros (LEQUARRE et al., 2004; ROBERT et al., 2002). Nossos resultados, portanto, concordam com relatos anteriores para oócitos bovinos. A ciclina seria preferencialmente armazenada na forma de RNAm em oócitos imaturos e só seria traduzida com a retomada da meiose (ROBERT et al., 2002).

A síntese de ciclina $B$ aumenta progressivamente com a meiose e corresponde com o aumento de atividade do MPF (WINSTON et al., 1997). Em bovinos, a síntese de ciclina B1 começa poucas horas do início da maturação e permanece até o final (LEVESQUE; SIRARD, 1996). Quando os oócitos foram observados após a maturação também houve o aparecimento da proteína em níveis elevados.

No caso dos oócito bloqueados, a ciclina B1 também se manteve não detectada e quando os oócitos foram maturados a proteína foi detectada de forma similar aos controles. Isso indica que a ciclina é traduzida ao longo da maturação e que o controle de sua tradução está relacionado ao estádio da meiose em que se encontra o oócito, ou seja, oócitos em VG recém-aspirados do folículo ou mantidos em bloqueio meiótico não apresentam a ciclina B1 na forma de proteína, mas quando são maturados a proteína aparece normalmente. Não foi relatado o efeito do bloqueio da meiose sobre a tradução da ciclina B1, mas como a expressão do RNA não foi afetada pelo bloqueio e como a presença da proteína foi detectada de forma similar aos controles, 
pode-se sugerir que o bloqueio da meiose não altera o controle da tradução da ciclina.

A MAPK exibiu uma expressão similar à da $\mathrm{p} 34^{\mathrm{cdc} 2}$, ou seja, foi detectada em oócitos imaturos e manteve-se presente nos oócitos maturados. Esses resultados concordam com descrições de outros estudos. A MAPK foi observada ao longo da maturação tanto em bovinos (KUBELKA et al., 2000) como em suínos (KUBELKA et al., 2002). Ebeling et al. (2007) observaram também que a MAPK além de estar presente nos oócitos é observada nas células do cumulus e que nestas se ativa mais precocemente no oócito, sugerindo que a retomada da meiose estaria relacionada à ativação da MAPK primeiramente nas células do cumulus e depois no oócito.

Quando os oócitos foram bloqueados a MAPK não foi afetada ao final do bloqueio ou após a maturação, como observado em outros estudos (KUBELKA et al., 2000; VIGNERON et al., 2004a). Essas observações indicam que a expressão da proteína da MAPK, importante fator envolvido no controle da maturação (LIANG et al., 2007), além do MPF, não é afetada pelo bloqueio da meiose e a presença de sua proteína é constante, variando apenas a sua atividade, como será visto no próximo experimento.

Os resultados de expressão das proteínas envolvidas na retomada da meiose, ou seja, os componentes do MPF p34 ${ }^{\text {cdc2 }}$ e ciclina B1 e a MAPK, tanto no nível de transcritos (RNAm) como de proteínas, não foram afetados pelo procedimento do bloqueio da meiose. As flutuações observadas foram somente relativas às variações normais que ocorrem durante o processo de maturação.

No experimento seguinte, procuramos avaliar o efeito do tratamento na atividade de MPF e MAPK. Os perfis de atividade de MPF e MAPK foram similares aos relatados anteriormente para oócitos não bloqueados antes da maturação (KUBELKA et al., 2000; WU et al., 1997). A ativação de ambas ocorreu próximo ao período estimado da quebra da VG ( $\sim 9$ h). Posteriormente, a atividade da MAPK manteve-se até o final da MIV (24 h), enquanto o MPF apresentou um ligeiro declínio em torno de $12 \mathrm{~h}$, seguido de recuperação com um segundo pico às $24 \mathrm{~h}$.

Quando os oócitos foram incubados com butirolactona I, as atividades de MPF e MAPK foram inibidas, mantendo-se similares aos de oócitos naturalmente imaturos ( 0 h de MIV) mesmo após 24 h de cultivo in vitro. Essas 
observações estão de acordo com relatos anteriores (KUBELKA et al., 2000; 2002; VIGNERON et al., 2004a), confirmando a inibição de MPF e de MAPK pela BLI. A BLI é um inibidor específico da cdk1, um dos componentes do MPF, sem atividade sobre a MAPK (KITAGAWA et al., 1993). A MAPK, porém, é inibida indiretamente pela falta de ativação do MPF (KUBELKA et al., 2000).

Apesar da inibição de MPF pela BLI, observamos que no grupo tratado (B10), algumas amostras de oócitos apresentaram um pouco de atividade de MPF no final do bloqueio, o que corresponderia ao início da maturação (0 h). Como a avaliação foi feita em pools de 5 oócitos, é possível que alguns oócitos tivessem "escapado" do bloqueio e iniciado a maturação, com ativação do MPF.

No entanto, se a ativação do MPF tivesse ocorrido de fato, seria esperado encontrar uma atividade muito mais elevada, o que não foi caso, pois não houve diferença entre os grupos. É possível, que ao serem colocados em meio de cultivo permissivo à maturação (sem inibidor), tenha havido uma ativação mais rápida do MPF em alguns dos oócitos, como sugerido pela a aceleração na retomada da meiose observada nos estudos anteriores e de outros pesquisadores (HASHIMOTO et al., 2002; WU et al., 2002). Isso, no entanto, não ficou evidente, visto que o grupo inibido não diferiu do controle nas etapas iniciais da maturação.

O acúmulo de ciclina B1 foi determinado como um dos elementos envolvidos na atividade do MPF e na cinética da maturação (LEVESQUE; SIRARD, 1996; WINSTON et al., 1997). A BLI inibe a subunidade cdk1 (p34 ${ }^{\text {cdc2 }) ~ d o ~ M P F ~(K I T A G A W A ~ e t ~ a l ., ~ 1993) . ~ A ~ c i c l i n a ~ B 1 ~ p o d e r i a ~ e s t a r ~ s e n d o ~}$ acumulada nesse período e ao remover-se o inibidor do meio de cultivo, esta maior quantidade de ciclina se ligaria ao $\mathrm{p} 34^{\mathrm{cdc} 2}$ pré-existente formando o MPF para ser ativado. No presente estudo a ciclina B1 não foi observada nos oócitos bloqueados imaturos. No entanto, como não foi feita uma análise da dinâmica da síntese de ciclina B1 ao longo da maturação, é possível que a proteína tenha sido sintetizada mais rapidamente. Porém, a atividade de MPF, que dependeria da presença da ciclina B1, não foi acelerada em relação ao controle.

A ativação do MPF não depende apenas da dimerização de suas subunidades, mas também da dinâmica de outras proteínas responsáveis pela 
fosforilação e desfosforilação que controlam sua atividade, como a Wee1/Myt1 e cdc25 fosfatase (KISHIMOTO et al., 2003; LIANG et al., 2007). Seria necessário investigar as atividades de outras proteínas para confirmar se a aceleração na meiose seria relacionada ao acúmulo mais rápido de ciclina B1 e/ou de outras proteínas envolvidas no controle da atividade do MPF. Vigneron et al. (2004b) sugeriram que proteínas como Akt, JNK1/2 e Aurora-A estariam envolvidas na aceleração da cinética da meiose e atuando de forma independente do MPF. Embora não tenhamos detectado alterações importantes na atividade de MPF, não se pode excluir a possibilidade de que alterações existam, mas que não foram significativas devido à alta variabilidade na detecção da atividade dessas proteínas cinases.

Oócitos inibidos e depois maturados exibiram o restabelecimento das atividades de forma similar aos não tratados. Esse bloqueio reversível também foi observado anteriormente (KUBELKA et al., 2000; VIGNERON et al., 2004a). Esses autores mostraram que oócitos imaturos por bloqueio ou não, tinham baixa atividade de MPF e MAPK e que os maturados, bloqueados ou não, tinham alta atividade. A avaliação da dinâmica da atividade de MPF e MAPK durante a maturação de oócitos submetidos ao bloqueio meiótico prévio, no entanto, não foi realizada. De acordo com nossas observações foram similares ao descrito anteriormente para oócitos apenas maturados (KUBELKA et al, 2000; MOTLIK et al., 1998).

Observou-se, porém, que embora a dinâmica de atividade de MPF tenha sido similar entre o grupo tratado e controle, houve apenas uma diferença significativa entre ambos ao final da maturação. Às 24 h de MIV o grupo B10 já tinha iniciado o declínio da atividade de MPF, enquanto os oócitos controles ainda apresentavam atividade elevada. Essa observação sugere uma inativação precoce da cinase e/ou que os oócittos tenham atingido a metáfase II, o que corresponderia ao segundo pico de MPF antecipado. Para B10, o segundo pico de MPF ocorreu às $21 \mathrm{~h}$, embora a atividade nesse horário não tenha diferido do controle. O grupo controle atingiu o segundo pico às $24 \mathrm{~h}$. Dessa forma, o B10 atingiu o segundo pico três horas mais cedo que o controle e os oócitos poderiam estar entrando em processo de envelhecimento, no qual ocorre um declínio natural da atividade de MPF (WU et al., 1997). Essa queda na atividade do MPF não parece ser, porém, o suficiente para causar danos 
importantes aos oócitos, visto que o desenvolvimento embrionário não foi afetado per esse tipo de tratamento (estudo 2 e COY et al., 2005a,b; HASHIMOTO et al., 2002; PONDERATO et al., 2002).

Além disso, observamos que a aceleração da meiose se dá mais em relação à retomada do ciclo celular do que seu término (estudo 1). A aceleração corresponderia bem a um acúmulo mais rápido de ciclina B1, visto que a síntese de sua proteína determina a duração da meiose I, mas não da meiose II (WINSTON, 1997). Sendo mais rápida, a meiose I seria mais curta e consequentemente o ciclo celular como um todo. No entanto, parece haver certa assincronia entre a atividade de MPF e a cinética da maturação, revelando que o controle do ciclo celular meiótico é um evento bastante complexo envolvendo uma série de fatores.

Em relação à atividade de MAPK, observamos que esta apresentou um padrão similar ao descrito durante a maturação oocitária. A atividade é baixa nos oócitos imaturos e torna-se ativa por volta do período de quebra da VG, similar ao observado com o MPF. A partir daí, mantém-se elevada até o final da maturação (KUBELKA et al., 2000). No grupo tratado o comportamento foi similar ao dos oócitos não tratados que utilizamos e ao relatado por outros autores (KUBELKA et al., 2000, 2002; VIGNERON et a.l, 2004a).

Também não há estudos da dinâmica dessa cinase durante a maturação de oócitos submetidos ao bloqueio prévio. Foi apenas observado em outros estudos que a BLI mantém a MAPK com atividade similar à de oócito imaturos não tratados e que esse bloqueio é reversível, pois após a maturação a atividade de MAPK se restabelece de forma similar à de oócitos maturados não bloqueados (KUBELKA et al., 2000; 2002; VIGNERON et al., 2004a). Apesar das poucas variações na atividade de MPF, a reativação da MAPK transcorreu normalmente, apesar de ser inibida indiretamente pela BLI em oócitos. Isso indica que o MPF é mais sensível a distúrbios de sua atividade e que talvez outras proteínas envolvidas no controle de sua atividade possam ser de alguma forma, afetadas pelo inibidor.

A distribuição da p34 ${ }^{\mathrm{cdc} 2}$ em oócitos imaturos de camundongos, descrita por Mitra e Schultz (1996), é similar à observada no presente estudo. Oócitos em vesícula germinativa apresentaram uma marcação granular em todo o citoplasma e também no no núcleo. Esses autores sugeriram que essa 
marcação nuclear teria relação com a competência meiótica do oócito e que a distribuição espacial das subunidades do MPF também teria relação com o controle da retomada da meiose.

Após a maturação, observou-se que a p34 ${ }^{\text {cdc2 }}$ localizou-se em torno dos cromossomos em metáfase II e no fuso (HUO et al., 2005). Nakamura et al. (2005) também observaram uma variação da marcação de p34 ${ }^{\text {cdc2 }}$ em embriões de Xenopus sp e que variou com a fase do ciclo celular meiótico. Em intérfase a p34 ${ }^{\mathrm{cdc2}}$ localizou-se no núcleo junto aos cromossomos e na metáfase na cromatina e no fuso. A proteína também estava presente no citoplasma de forma granular. Não há descrição da distribuição de p34 ${ }^{\mathrm{cdc} 2} \mathrm{em}$ oócitos bovinos imaturos ou maturados. Apesar de similar nos oócitos imaturos, a distribuição da $\mathrm{p} 34^{\mathrm{cdc} 2}$ nos oócitos maturados foi distinta da observada em camundongos (HUO et al., 2005). Não foi observada em oócitos bovinos em metáfase II uma distribuição diferenciada Essa discrepância poderia ser relacionadas à diferenças entre espécies.

Quando os oócitos foram bloqueados, a distribuição espacial da p34 ${ }^{\text {cdc2 }}$ foi similar à de oócitos imaturos sem bloqueio. Esse resultado indica que a p34 ${ }^{\text {cdc2 }}$ mantém o padrão de distribuição do oócito imaturo recém-aspirado durante o bloqueio meiótico. Após a maturação dos oócitos bloqueados, a p34 ${ }^{\text {cdc2 }}$ foi observada com uma localização indistinta da de oócitos maturados sem bloqueio prévio. Em embriões de Xenopus sp a localização da p34 ${ }^{\mathrm{cdc} 2}$ é dependente de microtúbulos e microfilmentos (NAKAMURA et al., 2005). Como relatado no estudo 2 a organização do citoesqueleto de oócitos bloqueados também se manteve similar à de oócitos imaturos, sugerindo que o inibidor não tenha afetado negativamente essas estruturas celulares.

A ciclina B1 apresentou uma distribuição uniforme em todo o citoplasma nos oócitos imaturos ou maturados. Essa distribuição difere do relatado em outras espécies. Em oócitos de camundongos imaturos a ciclina B1 foi localizada no citoplasma e, ao contrário do observado para a p34 ${ }^{\text {cdc2 }}$, a intensidade de fluorescência foi menor nos oócitos competentes e também presente no núcleo (MITRA; SCHULTZ, 1996). Quando uma ciclina B1 conjugada a uma proteína fluorescente verde foi injetada em oócitos imaturos, observou-se que a mesma se distribuiu pelo citoplasma. Depois de algum 
tempo acumulou-se no núcleo para logo depois ocorrer a quebra da VG. Em metáfase II foi localizada nos pólos do fuso, micrtúbulos e na cromatina.

Foi sugerido que a localização nucelar da ciclina B1 seria necessária para a quebra da (MARANGOS; CARROLL, 2004). A detecção por imunofluorescência e microscopia confocal também resultou em observações similares (HUO et al., 2005). Em oócitos suínos, a ciclina B foi observada dispersa no citoplasma de oócitos em VG, dentro da VG pouco antes do período correspondente à quebra da mesma e depois nos cromossomos em metáfase II (CASAS et al., 1999). Na mesma espécie, porém, Goto et al., (2002) observaram a ciclina nos pólos do fuso e fraca marcação no citoplasma.

Em embriões de Xenopus sp a ciclina também tem localização variada de acordo com a fase do ciclo mitótico, mas ao contrário da p34 ${ }^{\text {cdc2 }}$ sua localização não é dependente de microtúbulos ou microfilamentos (NAKAMURA et al., 2005). Esses estudos demonstram uma variação na distribuição dessa proteína dependendo do estádio de maturação e variações entre espécies. É possível que na espécie bovina haja diferenças na localização dessa proteína em relação às outras espécies descritas, ou que em bovinos a localização não seja um mecanismo tão importante para o controle da meiose e para a competência como sugerido nesses estudos. Seria interessante, porém, averiguar a dinâmica da distribuição da ciclina e da p34 ${ }^{\text {cdc2 }}$ ao longo da maturação, pois talvez as variações sejam detectadas em estádios da meiose entre a VG e a metáfase II.

Em nosso estudo também não observamos localização diferenciada antes e após a maturação, quando os oócitos foram previamente bloqueados, indicando que o bloqueio também não interferiu na localização da ciclina. De toda forma, a detecção e localização dos componentes do MPF são importantes para determinar se o tratamento do bloqueio meiótico poderia causar distúrbios na distribuição dessas proteínas. A distribuição de p34 ${ }^{\mathrm{cdc2}} \mathrm{e}$ ciclina B foi sugerida como um mecanismo de regulação da atividade da MPF (NAKAMURA et al., 2005). Além do processo de fosforilação para ativação do MPF, a localização espacial também é importante para o controle da meiose por essa cinase (MARANGOS; CARROLL, 2005). Estudos são necessários para determinar a localização dessas proteínas ao longo da maturação e também seu papel, se houver algum. 
Em relação à MAPK, a mesma foi detectada como finas granulações em todo o citoplasma nos oócitos imaturos e maturados, bloqueados ou não, com distribuição similar em todos os grupos. A MAPK em oócitos suínos imaturos foi detectada em todo o citoplasma,mas não no núcleo (INOUE et al., 1998), diferindo dos resultados do presente estudo. Foi sugerido que a MAPK participaria da transdução de sinal do citoplasma para o núcleo para a retomada da meiose, visto que parte da MAPK transloca para o núcleo pouco antes da GVBD (INOUE et al., 1998; SUGIURA et al., 2001).

Quando o oócito atinge a metáfase II, a MAPK localiza-se mais intensamente entre os cromossomos e o corpúsculo polar, o que sugere que sua localização tenha relação com suas funções na separação dos cromossomos, no alongamento do fuso e na extrusão do corpúsculo polar (LEE et al., 2000). Goto et al. (2002) também observaram que a MAPK encontra-se mais concentrada no fuso, mas que a atividade da enzima era mais localizada no citoplasma. O significado dessa localização é incerto visto que em oócitos enucleados a MAPK torna-se ativa em níveis normais e com cinética também normal (SUGUIRA et al, 2001; 2006).

Ao avaliar a localização da MAPK ativa (fosforilada) em oócitos murinos, observou-se que ela não era detectada nos oócitos até depois da quebra da VG, quando aparece localizada nos microtúbulos do fuso na metáfase I e nos cromossomos em metáfase II. Os autores sugeriram que a ativação da MAPK e a translocação para o núcleo não são necessárias para a quebra da VG, mas a regulação de eventos após esse período (LU et al., 2002). Essas observações contrastam com os resultados com oócitos suínos em que a translocação nuclear e ativação da MAPK ocorrem pouco antes da quebra da VG (INOUE et al., 1998). No entanto, parece que a presença da VG não é essencial para a atividade da MAPK (SUGUIRA et al., 2006).

Esses resultados são diferentes de nossas observações, mas foram todos obtidos em oócitos suínos e murinos, não havendo relatos para bovinos. Talvez existam diferenças entre espécies. Oócitos murinos, por exemplo, não dependem de síntese protéica para retomar a meiose (MOTLIK et al., 1990), enquanto que em bovinos é necessária (TATEMOTO; HORIUCHI, 1995). A translocação de MAPK para o núcleo ocorre antes da quebra da VG em suínos 
(INOUE et al., 1998) e depois em murinos (LU et al., 2002). No entanto, como não avaliamos a distribuição dessas proteínas ao longo da maturação, é possível que padrões diferenciados sejam observados também em bovinos, em particular, no período da quebra da VG. São necessários estudos para determinar a dinâmica da localização da MAPK e a relação disso com sua atividade e o controle da meiose.

Os oócitos bloqueados, maturados ou não, não apresentaram diferenças na localização da MAPK, sugerindo que o bloqueio também não interfere com a localização dessa proteína nas condições estudadas. 


\section{CONCLUSÕES}

Diante dos resultados desse estudo, pode-se concluir que:

1) A maturação afeta de forma diferenciada a expressão de RNA dos componentes do MPF e a MAPK, enquanto o bloqueio da meiose mantém o mesmo padrão de expressão de acordo com o estádio da maturação dos oócitos;

2) A expressão das proteínas p34, ciclina B1 e MAPK forma afetadas somente pelo processo de maturação, sugerindo que o processo de tradução das mensagens foi controlado de acordo com o estádio da meiose e não foi afetado pelo bloqueio da meiose;

3) As atividades de MPF e MAPK não foram afetadas pelo bloqueio meiótico;

4) A distribuição das proteínas mostrou padrões distintos dependendo do estádio de maturação apenas para e p34 e não foi afetada pelo bloqueio meiótico, nas condições estudadas;

5) O bloqueio da meiose como inibidor específico de proteínas cinases dependentes de ciclinas, nas condições desse estudo, não afetaram a expressão, localização subcelular ou atividade de MPF e MAPK antes e após a maturação. 


\section{REFERÊNCIAS}

ABRIEU A, DORÉE M, FISHER D. The interplay between cyclin-B-Cdc2 kinase (MPF) and MAP kinase during maturation of oocytes. Journal of Cell Science, v. 114, p.257-267, 2001.

ADONA, P.R.; LEAL, C.L.V. Meiotic inibition with different cyclin-dependent kinase inhibitors in bovine oocytes and its effects on maturation and embryo development. Zygote, v.12, p.197-204, 2004.

ALBRARRACÍN JL, MOARATÓ R, IZQUIERDO D, MOGAS T. Effects of roscovitine on the nuclear and cytoskeletal components of calf oocytes and their subsequent development. Theriogenology, v.64, p.1740-1755, 2005.

ANDRIESZ C, FONG CY, BONGSO A, TROUNSON AO. Regulation of human and mouse oocyte maturation in vitro with 6-dimethylaminopurine. Human Reproduction v15, p.79-388, 2000.

ANGUITA, B., JIMENEZ-MACEDO, A.R., IZQUIERDO, D., MOGAS, T., PARAMIO, M.T. Effect of oocyte diameter on meiotic competence, embryo development, p34 (cdc2) expression and MPF activity in prepurbetal goat oocytes. Theriogenology, v. 67, p.526-536, 2007.

ARLOTTO T, SCHWARTZ JL, FIRST NL, LEIBFRIED-RUTLEDGE ML. Aspects of follicle and oocyte stage that affect in vitro maturation and development of bovine oocytes. Theriogenology, v.46, p.943-956, 1996.

ASSEY RJ, HYTTEL P, GREVE T, PURWANTARA B. Oocyte morphology in domainant and subordinate follicles. Mol. Reprod. Dev, v.37, p.335-344, 1994.

AVERY B, HAY-SCHIMIDT A, HYTTEL P, GREVE T. Embryo development, oocyte morphology, and kinetics of meiotic maturation in bovine oocytes exposed to 6-dimethylaminopurine prior to in vitro maturation. Mol. Reprod. Dev, v.50, p.334-344, 1998. 
BARRETTO, L.S.S., CAIADO CASTRO, V.S.D., GARCIA, J.M., MINGOTI, G.Z., 2007. Role of roscovitine and IBMX on kinetics of nuclear and cytoplasmic maturation of bovine oocytes in vitro. Anim. Reprod. Sci. 99, 202-207.

BLONDIN P, COENEN K, GUILBAULT LA, SIRARD MA. In vitro production of bovine embryos: developmental competence is acquired before maturation.

Theriogenology, v.47, p.1061-1075,1997.

BLONDIN P, BOUSQUET D, TWAGIRAMUNGU H, BANRES F, SIRARD MA. Manipulation of follicular development to produce developmentally competent bovine oocytes. Biol. Reprod v. 66, p.38-43, 2002.

BEKER van WOUNDENBERG AR, ZEINSTRA EC, ROELEN BAJ, COLENBRANDER B, BEVERS MM. Developmental competence of bovine oocytes after specific inhibition of MPH kinase activity: effect of estradiol supplementation and follicle size. Animal Reproduction Science, v.92, p.231240, 2006.

BILODEAU-GOESEELS S. Effects of phosphodiesterase inhibitors on spontaneous nuclear maturation and cAMP concentrations in bovine oocytes. Theriogenology v. 60, p.1679-1690, 2003.

BILODEAU-GOESEELS S. Effects of culture media and energy sources on the inhibition of nuclear maturation in bovine oocytes. Theriogenology 2006; no prelo. Disponível on-line em dezembro 2005.

BREVINI, T.A.L., CILLO, F., ANTONINI, A., GANDOLFI, F. Cytoplasmic remodeling and the acquisition of developmental competence in pig oocytes.

Anim. Reprod. Sci., v. 98, p.23-38, 2007a. 
BREVINI, T.A.L., CILLO, F., ANTONINI, A., TOSETTI, V., GANDOLFI, F. Temporal and spatial control of gene expression in early embryos of farm animals. Reprod Fert Dev., v. 19, p.35-42, 2007b.

BRUNET, S., MARO, B., 2005. Cytoskeleton and cell cycle control during meiotic maturation of the mouse oocyte, integrating time and space. Reproduction 130, 801-811.

CALLESEN H, GREVE T, HYTTEL P. Preovulatory endocrinology and oocyte maturation in superovulated cattle. Theriogenology, v.43, p.1115-28, 1986.

CAN, A.; SEMIZ, O.; ÇINAR, O. Centrosome and microtubule dynamics during early stages of meiosis in mouse oocytes. Molecular Human Reproduction. v. 9, p.749-56, 2003.

CASAS E, BETANCOURT M, BONILLA E, DUCULOMB Y, ZAYAS H, TREJO $\mathrm{R}$. Changes in cyclin B localisation during pig oocyte in vitro maturation. Zygote, v.7, p.21-26, 1999.

CASTRO A, PETER M, MAGNAGHI-JAULIN L, VIGNERON S, GALAS S, LORCA T, LABBE J-C. Cyclin B/cdc2 induces C-mos stability by direct phosphorylation in Xenopus oocytes. Molecular Biology of the Cell., v. 12, p.2660-2671, 2001.

CHA K-Y, CHIAN R-C. Maturation in vitro of immature human oocytes for clinical use. Human Reproduction Update, v. 4, p.103-120, 1998.

CHRISTMANN, L., JUNG, T., MOOR, R.M. MPF components and meiotic competence in growing pig oocytes. Mol. Reprod. Dev., v.38, p.85-90, 1994.

COENEN K, MASSICOTTE L, SIRARD MA. Study of newly synthesized proteins during bovine oocyte maturation in vitro using image analysis of twodimensional gel electrophoresis. MOLECULAR REPRODUCTION AND DEVELOPMENT, v. 67, p. 313-322, 2004. 
CONNORS, S.A., KANATSU-SHINOHARA, M., SCHULTZ, R.M., KOPF, G.S. . Involvement of the cytoskeleton in the movement of cortical granules during oocyte maturation, and cortical granule anchoring in mouse eggs. Dev. Biol. 200, 103-115, 1998.

CONTI M, ANDERSEN CB, RICHARD FJ, SHITSUKAWA K, TSAFIRI A. Role of cyclic nucleotide phosphodiesterases in resumption of meiosis. Molecular and Cellular Endocrinology, v.145, p.9-14, 1998.

COY P, ROMAR R, RUIZ S, CÁNOVAS S, GADEA J, VÁZQUEZ FG, MATÁS $\mathrm{C}$, Birth of piglets after transferring of in vitro-produced embryos pre-matured with R-roscovitine. Reproduction, v.129, p.747-755, 2005b.

CRAN, D.G.; ESPER, C.R. Cortical granules and the cortical reaction im mammals. J.Reprod.Fertil.Suppl. v.42, p.177-8, 1990.

DAMIENS, E. \& MEIJER, L. (2000). Inihibiteurs chimiques des kinases cyclinedépendentes: études précliniques et cliniques. Pathol. Biol. 48, 340-341.

DAYAN, A., WATANABE, M.R., WATANABE, Y. Fatores que interferem na produção comercial de embriões FIV. Arq. Fac. Vet. UFRS, v.28, p.181-185, Supl 1, 2000.

DE LOOS F, KASTROP P, VAN BENEDEN TH, KRUIP TA. Heterologous cell contacts and metabolic coupling in bovine cumulus oocyte complexes. Molecular Reproduction and Development, v. 28, p. 255-259, 1991.

De SOUSA PA, CAVENEY A, WESTHUSIN ME, WATSON AJ. Temporal patterns of embryonic gene expression and their dependence on oogenetic factors. Theriogenology, v. 49, p.115-128, 1998.

DIELEMAN, S.J., HENDRIKSEN, P.J.M., VIUFF, D., THOMSEN, P.D., HYTTEL, P., KNIJIN, H.M., WRENZYCHI, C., KRUIP, T.A.M., NIEMANN, H., GADELLA, B.M., BEVERS, M.M., VOS, P.L.A.M. Effects of in vivo 
prematuration and in vivo final maturation on developmental capacity and quality of pre-implantation embryos. Theriogenology, v. 57, p.5-20, 2002.

DODE MAN, ADONA PR. Developmental capacity of Bos indicus oocytes after inhibition of meiotic resuption by 6-dimethyminopurine. Animal Reproduction Science, v.5, p.171-180, 2001.

DONNAY I, FAERGE I, GRONDAHL C, VERHAEGHE B, SAYOUD H, PONDERATO N, GALLI C, LAZZARI G. Effect of prematuration, meiosis activating sterol and enriched maturation medium on the nuclear maturation and competence to development of calf oocytes. Theriogenology, v.62, p.10931107, 2004.

DUCKWORTH BC, WEAVER JS, RUDERMAN JV. $\mathrm{G}_{2}$ arrest in Xenopus oocytes depdends on phosphorylation of cdc25 by protein kinase A. PNAS, v. 99, p.16794-16799, 2002.

EDRY I, SELA-ABRAMOVICH S, DEKEL N. Meiotic arrest depends on cell-tocell communication in the ovarian follicle. Molecular and Cellular Endocrinology, v.252, p.102-106, Sp. Iss., 2006.

EYERS PA, LIU J, HAYASHI NR, LEWELLYN AL, GAUTIER J, MALLER JL. Regulation of the $\mathrm{G}(2) / \mathrm{M}$ transition in Xenopus oocytes by the cAMP-dependent protein kinase. The Journal of Biological Chemistry, v. 280, p.24339-24346, 2005.

FAIR, T.; HYTTEL, P.; MOTLIK, J.; BOLAND, M.; LONERGAN, P. Maintenance of meiotic arrest in bovine oocytes in vitro using butyrolactone I: Effects on oocyte ultrastructure and nucleolus. Molec. Reprod. Dev., v.62, p.375-386, 2002.

FAERGE, I., MAYES, M., HYTTEL, P., SIRARD, M.A., 2001. Nuclear ultrastructure in bovine oocytes after inhibition of meiosis by chemical and biological inhibitors. Mol. Reprod. Dev. 59, 459-467. 
FARIA, CC; ROCHA, AA; LEAL, CLV; ADONA, PR; UENO, VG. Efeito da bohemina na retenção da meiose em ovócitos bovinos in vitro. Rev. Bras. Reprod. Anim., v. 26, p 151-154, 2002.

FISSORE RA, HE CL, VAN De WOUDE GF. Potential role of mitogen-activated protein kinase during meiosis resumption in bovine oocytes. Biology of Reproduction, v. 55, p.1261-1270, 1996.

FLAMENT S., BODART J.F., BERTOUT M., BROWAEYS E., ROUSSEAU A., VILAIN J.P. (2000). Differential effects of 6-DMAP, olomoucine and roscovitine on Xenopus oocytes and eggs. Zygote 8, 3-14.

GANDOLFI, B.T.A.L.; GANDOLFI, F. The maternal legacy to the embryo: cytoplasmic components and their effects on early development.

Theriogenology, v. 55, p.1255-1276, 2001.

GOREN,S.; DEKEL,N. Maintence of meiotic arrest by a phosphorylated p34 is dependent of cyclic adenosine 3'-5'-monophosphate. Biol. Reprod. v. 51, p.956-62, 1994.

GOTO S, NAITO K, OHASHI S, SUGIURA K, NARUOKA H, IWAMORI N, TOJO $\mathrm{H}$. Effects of spindle removal on MPF and MAPK activities in porcine matured oocytes. Mol Reprod Dev, v.63, p.388-393, 2002.

GRUPEN CG, FUNG M, ARMSTRONG AT. Effects of milrinone and butyrolactone-I on porcine oocyte meiotic progression and developmental competence. Reproduction, Fertility and Development, v.18, p.309-317, 2006.

HAN D, L GC, WU YG, HAN ZB, WANG HL, TAN JH. Factors affecting the efficiency and reversibility of roscovitine (ROS) block on the meiotic resumption of goat oocytes. Molecular Reproduction and Development, v.73, p.238-246, 2006. 
HASHIMOTO S, MINAMI N, TAKAKURA R, IMAI H. Bovine immature oocytes acquire developmental competence during meiotic arrest in vitro. Biology of Reproduction, v. 66, p.1696-1701, 2002.

HASHIMOTO S, KIMURA K, IWATA H, TAKAKURA R. Oocyte transport: developmental competence of bovine oocytes arrested atgerminal vesicla stage by cycloheximide under air. Journal of Reproduction and Development, v. 49, p.61-66, 2003.

HENDRIKSEN, P.J.M., VOS, P.L.A.M., STEENWEG, W.N.M., BEVERS, M.M., DIELEMAN, S.J. Bovine follicular development and its effect on the in vitro vompetence of oocytes. Theriogenoology, v.53,p.11-20, 2000.

HINRICHS K, LOVE CC, CHOI YH, VARNER DD, WIGGINS CN, REINOEHL C. Suppression of meiosis by inhibitors of $m$-phase in horse oocytes with low meiotic competence. Zygote, v.10, p.37-45, 2002.

HIRAO, Y., NISHIMOTO, N., KURE-BAYASHI, S., TAKENOUCHI, N., YAMAUCHI, N., MASUDA, H., NAGAI, T., 2003. Influence of meiotic inhibition by butyrolactone-I during germinal vesicle stage on the ability of porcine oocytes to be activated by electric stimulation after nuclear maturation. Zygote 11, 191-197.

HYTTEL, P.; FAIR, T.; CALLESEN, H.; GREVE, T. Oocyte growth capacitation and final maturation in cattle.Theriogenology, v. 47, p.23-32, 1997.

HYTTEL, P. ; VIUFF, D.; FAIR, T.; LAURINCIK, J.; THOMSEN, P.D.; CALLESEN, H.; VOS, P.L.A.M.; HENDRICKSEN, P.J.M.; DIELEMAN, S.J.; SCHELLANDER, K.; BESENFELDER, U.; GREVE, T. Ribosomal RNA gene esxpression and chromossome aberrations in bovine oocytes and preimplantation embryos. Reproduction, v.122, p.21-30, 2001. 
HOLM P, CALLESEN H. In vivo versus in vitro produced bovine ova: similarities and differences relevant for practical application. Reprod Nuttrition Dev, v. 38, p.579-594, 1998.

HUO LJ, YU LZ, LIANG CG, FAN HY, CHEN DY, SUN QY. Cell-cycledependent subcellular localization of cyclin B1, phosphorylated cyclin B1 and p34 ${ }^{\text {cdc2 }}$ during oocyte meiotic maturation and fertilization in mouse. Zygote, v. 13, p. 45-53, 2005.

IMAI K, KOBAYASHI S, KANEYAMA K, KOJIMA T, NAGAI T. Effects of butyrolactone I on GVBD in bovine oocytes and subsequent maturation, fertilization and development in vitro. Journal Reproduction and Development, v.48, p.249-255, 2002.

INOUE M, NAITO K, NAKAYAMA T, SATO E. Mitogen-activated protein kinase translocates into the germinal vesicle and induces germinal vesicle breakdown in porcine oocytes. Biology of Reproduction, v. 58, p.130-136, 1998.

IZADYAR, F., ZEINSTRA, E., BEVERS, M.M. Follicle-stimulating hormone and growth hormone act differently on nuclear maturation while both enhance developmental competence of in vitro matured bovine oocytes. Mol. Reprod. Dev., v.51, p.339-345, 1998.

JIMENEZ-MACEDO AR, IZQUIERDO D, URDANETA A, ANGUITA B, PARAMIO MT. Effect of roscovitine on nuclear maturation, MPF and MAP kinase activity and embryo development of pubertal goat oocytes. Theriogenology, v. 65, p.1769-1782, 2006.

JONES KT. Turning it on and off: M-phase promoting factor during meiotic maturation and fertilization. Molecular Human Reproduction, v. 10, p.1-5, 2004. 
JOSEFSBERG LB-Y, DEKEL N. Translational and post-translational modifications in meiosis of the mammalian oocyte. Molecular and Cellular Endocrinology. v.187, p.161-171, 2002.

JU JC, TSAY C, RUAN CW. Alterations and reversibility in the chromatin, cytoskeleton and development of pig oocytes treated with roscovitine. Molecular Reproduction and Development, v.64, p.482-491, 2003.

KANO F, TAKENAKA K, YAMAMOTO A, NAGAYAMA K, NISHIDA E, MURATA $M . M E K$ and $C d c 2$ kinase are sequentially required for golgi disassembly in MDCK cells by the mitotic xenopus extracts. The Journal of Cell Biology, v. 149, p.357-368, 2000.

KIKUCHI K, NAITO K, NOGUCHI J, SHIMADA A, KANEKO K, YAMASHITA $\mathrm{M}$, TOJO $\mathrm{H}$, TOYODA $Y$. Inactivation of $\mathrm{p} 34^{\mathrm{cdc} 2}$ kinase by the accumulation of its phosphorylated forms in porcine oocytes matured and aged in vitro. Zygote, v.7, p.173-179, 1999.

KIKUCHI K, NAITO K, NOGUCHI J, SHIMADA A, KANEKO H, YAMASHITA M, AOKI F, TOJO H, TOYODA Y. Maturation/M-phase promoting factor: A regulator of aging in porcine oocytes. Biology of Reproduction, v. 63, p.715722, 2000.

KIM, N.H.; FUNAHASHI, H.; PRATHER, R.S.; SCHATTEN, H.; DAY, B.D. Microtubule and microfilament dynamics in porcine oocytes during meiotic maturation. Mol. Reprod. Dev., v.43, p.248-255, 1996.

KIM, N.H. et al. The distribution and requirements of microtubules an microfilaments in bovine oocytes in vitro maturation. Zygote, v.8, p.25-32, 2000.

KITAGAWA M., OKABE, T., OGINO H., MATSUMOTO H., SUZUKITAKASHI I., KOKUBO T., HIGASHI H., SAITOH S., TAYA Y., YASUDA H., OHBA Y., NISHIMURA S, TANAKA N., OKUYAMA A. Butyrolactone-I, a selective inhibitor 
of cdk2 and cdc2 kinase. Oncogene 8, 2425-2432, 1993.

KNOCKAERT, M., GREENGARD, P., MEIJER, L. Pharmacological inhibitors of cyclin-dependent kinases. Trends in Pharmacological Sciences 23, 417-425, 2002.

KOTSUJI, F.; KUBO, M.; TOMINAGA, T. Effect of interactions between granulose and thecal cells on meiotic arrest in bovine oocytes. Journal of Reproduction and Fertility, v. 100, p.151-6, 1994.

KRISCHEK C, MEINECKE B. In vitro maturation of bovine oocytes requires polyadenylation of mRNAs coding proteins for chromatin condensation, spindle assembly, MPF and MAP kinase activation. Animal Reproduction Science, v.73, p.129-140, 2002.

KRUIP,T.A.M.; CRAN,D.G.;VAN,B.T.H.; DIELEMAN,S.J. Structural changes in bovine oocytes during final maturation in vivo. Gamete Res. v.8, p.29-47, 1983.

KUBELKA, M.; MOTLI'K, J.; SCHULTZ, R.M.; PAVLOK, A.. Butyrolactone I reversibly inhibits meiotic maturation of bovine oocytes, without influencing chromosome condensation activity. Biol Reprod., v.62, p.292-302, 2000.

KUBELKA M, AANGER M, KALOUS J, SSCHULTZ RM, MOTLIK J.

Chromosome condensation in pig oocytes: lack of a requirement for either cdc2 kinase or MAP kinase activity. Molecular Reproduction and Development, v. 63, p. 110-118, 2002.

LAEMMLI, U.K. Cleavage of structural proteins during the assembly of the head of the bacteriophage T4. Nature, v.227, p.680-685, 1970.

LAGUTINA I, PONDERATO N, LAZZARI G, GALLI C. Kinetics of oocyte maturation and subsequent development of IVF, parthenogenetic, and NT bovine embryos after meiotic inhibition with roscovitinre. Cloning and Stem Cells, v.4, p.113-119, 2002. 
LE BEAUX G, RICAHRD FJ, SIRARD MA. Effect of cycloheximide, 6-DMAP, roscovitine and butyrolactone I on resumption of meiosis in porcine oocytes. Theriogenology, v.60, p.1049-1058, 2003.

LEDAN E, POLANSKI Z, TERRET M-E, MARO B. Meiotic Maturation of the Mouse Oocyte Requires an Equilibrium between Cyclin B Synthesis and Degradation. Developmental Biology, v.232, p.400-413, 2001.

LEE J, MIYANO T, MOOR RM. Localisation of phosphorylated MAP kinase during the transition from meiosis I to meiosis II in pig oocytes. Zygote, v.8, p.119-125, 2000.

LEFEBVRE C, TERRET ME, DJIANE A, RASSINIER P, MARO B, VERLHAC $\mathrm{M}-\mathrm{H}$. Meiotic spindle stability depends on MAPK-interacting and spindlestabilizing protein (MISS), a new MAPK substrate. The Journal of Cell Biology, v. 157, p.603-613, 2002.

LEQUARRE AS, TRAVERSO JM, MARCHANDISE J, DONNAY I. Poly(A) RNA is reduced by half during bovine oocyte maturation but increases when meiotic arrest is maintained with CDK inhibitors. Biology of Reproduction, v. 71, p.425-431, 2004.

LEVESQUE JT, SIRARD MA. Resumption of meiosis is initiated by the accumulation of cyclin B in bovine oocytes. Biol. Reprod., v.55, p.1427-1436, 1996.

LIN, L., LEE, C., MOOR, R.M. DNA synthesis, microtubule and nuclear dynamics in porcine parthenotes. Zygote, v.4, p.139-144, 1996.

LONERGAN, P. et al. Factors influencing oocyte and embryo quality in cattle. Reprod. Nutr. Dev., v.41, p.1-11, 2001. 
LONERGAN, P.; KHATIR, H.; CAROLAN, C.; MERMILLOD

, P. Bovine blastocyst production in vitro after inhibition of oocyte meiotic resumption for 24 h. J. Reprod. Fert; v. 109, p. 355-365, 1997

LONERGAN P, DINNYÉS A, FAIR T, YANG X, BOLAND M. Bovine oocyte and embryo development following meiotic inhibition with butyrolactone I. Molecular Reproduction and Development, v. 57, p.204-209, 2000.

LONERGAN P, FAERGE I, HYTTEL PM, BOLAND M, FAIR T. Ultrastructural modifications in bovine oocytes maintained in meiotic arrest in vitro using roscovitine or butyrolactone. Molecular Reproduction and Development., v. 64:, p. 69-378, 2003.

LU Q, DUNN RL, ANGELES R, SMITH GD. Regulation of spindle formation by active mitogen-activated protein kinase and protein phosphatase 2A during mouse oocyte meiosis. Biol Reprod, v. 66, p. 29-37, 2002.

MARANGOS P, CARROLL J. The dynamics of cyclin B1 distribution during meiosis I in mouse oocytes. Reproduction, v. 128, p. 153-162, 2004.

MARCHAL, R., TOMANEK, M., TERQUI, M., MERMILLOD, P. Effect of cell cycle dependent kinases inhibitor on nuclear and cytoplasmic maturation of porcine oocytes. Mol. Reprod. Dev. 60, 65-73, 2001.

MAYES, M.; SIRARD, M.A. The influence of cumulus-oocyte complex morphology and meiotic inhibitors on the kinetics of nuclear maturation in cattle. Theriogenology, v. 55, p.911-22, 2001.

MAYES, M. The meiotic arrest of bovine oocytes. 2002. Tese (Doutorado), Université Laval, Canadá 2002.

MEHLMAN LM. Stops and starts in mammalian oocytes: recent advances in understanding the regulation of meiotic arrest and oocyte maturation.

Reproduction, v. 130, p.791-799. 2005. 
MEIJER L., BORGNE A., MULNER O., CHONG J.P.J., BLOW J.J., INAGAKI N., INAGAKI M., DELCROS J.G., MOULINOUX J.P. Biochemical and cellular effects of roscovitine, a potent and selective inhibitor of the cyclin-dependent kinases cdc2, cdk2 and cdk5. Eur. J. Biochem., 243, 527-536, 1997.

MEINECKE B, JANAS U, PODHAJSKY E, MEINECKE-TILLMANN S. Histone $\mathrm{H} 1$ and MAP kinase activities in bovine oocytes following protein synthesis inhibition. Reproduction in Domestic Animals, v. 36, p. 183-188, 2001.

MEIRELLES FV, CAETANO AR, WATANABE YF, RIPAMONTE P, CARAMBULA SF, MERIGHE GK, GARCIA SM. Genome activation and developmental block in bovine embryos. Animal Reproduction Science, v.82, p. 13-20, 2004.

MEMILI E, FIRST NL. Zygotic and embryonic gene expression in cow: a review of timing and mechanisms of early gene expression as compared with other species. Zygote, v. 8, p. 87-96, 2000.

MERMILLOD P, TOMANEK M, MARCHAL R, MEIJER L. High developmental competence of cattle oocytes maintained at the germinal vesicle stage for 24 hours in culture by specific inhibition of MPF kinase activity. Molecular Reproduction and Development, v.55, p.89-95, 2000.

MITRA J, SCHULTZ RM. Regulation of the acquisition of meiotic competence in the mouse: changes in the subcellular localization of cdc2, cyclin B1, cdc25C and wee1, and in the concentration of these proteins and their transcripts. J Cell Sci., v.109, p.2407-2415, 1996.

MONNIAUX D, MONGET P, BESNARD N, HUET C, PISSELET C. Growth factors and antral follicular development in domestic ruminants. Theriogenology, v.47, p.3-12, 1997. 
MOTLIK J, PAVLOK A, LAPATHITIS G, KUBELKA M. Impact of two-step in vitro culture systems on developmental potency of oocytes. Reprod. Dom. Anim , v. 35, p. 267-271, 2000.

MOTLIK,J.; PAVLOK,A.; KUBELKA,M. Interplay between cdc2 kinase and MAP kinase pathway during maturation of mammalian oocytes. Theriogenology, v.49, p.461-9, 1998.

NAKAMURA, N., TOKUMOTO, T., UENO, S., IWAO, Y. The cytoskeletondepedent localization of cdc2/cyclin B in blastomere cortex during Xenopus embryonic cell cycle. Mol. Reprod. Dev., v. 72, p.336-345, 2005.

NEBREDA AR, FERBY I. Regulation of the meiotic cell cycle in oocytes. Current Opinion in Cell Biology, v.12, p. 666-675, 2000.

NOGUEIRA D, CORTVRINDT R, DE MATOS DG, VANHOUTTE L, SMITZ J. Effect of phosphodiesterase type 3 inhibitor on developmental competence of immature mouse oocytes in vitro. Biology of Reproduction, v.69, p.20452052, 2003.

NOGUEIRA D, RON-EL R, FRIEDLER S, SCHACHTER M, RAZIEL A, CORTVINDT R, SMITZ J. Meiotic arrest in vitro by phosphodiesterase 3inhibitor enhances maturation capacity of human oocytes and allows subsequent embryonic development. Biology of Reproduction, 2006.

PAVLOK A, KANKA J, MOTLIK J, VODICKA P. Culture of bovine oocytes from small antral follicles in meiosis-inhibiting medium with butyrolactone I: RNA synthesis, nucleolar morphology and meiotic competence. Anim. Reprod. Sci, v.64, v.1-11. 2000.

PICTON HM. Activation of follicle development: the primordial follicle. Theriogenology; v. 55, p. 1193-210, 2001. 
PONDERATO, N., CROTTI, G., TURINI, P., DUCHI, R., GALLI, C., LAZZARI, G. Embryonic and foetal development of bovine oocytes treated with a combination of butyrolactone I and roscovitine in an enriched medium prior to IVM and IVF. Mol. Reprod. Dev. 62, 513-518, 2002.

PONDERATO N, LAGUTINA I, CROTTI G, TURINI P, GALLI C, LAZZARI G. Bovine oocytes treated prior to in vitro maturation with combination of butyrolactone I and roscovitine at low doses maintain a normal developmental capacity. Molecular Reproduction and Development, v. 60, p. 579-585, 2001.

RIZOS D, FAIR T, PAPADOPOULOS S, BOLAND M, LONDERGAN P. Developmental, qualitative, and ultrastructural differences between ovine and bovine embryos produced in vivo or in vitro. Mol. Reprod. Dev., v. 62, p. 320$327,2002 a$.

RIZOS D, WARD F, DUFFY P, BOLAND M, LONERGAN P. Consequences of bovine oocyte maturation, fertilization or early embryo development in vitro versus in vivo: Implications for blastocyst yield and blstocyst quality. Molecular Reproduction and Development, v.61, p.234-248, 2002b.

ROBERT C, HUE I, MCGRAW S, GAGNE D, SIRARD MA. Quantification of cyclin B1 and p34(cdc2) in bovine cumulus-oocyte complexes and expression mapping of genes involved in the cell cycle by complementary DNA macroarrays. Biol. Reprod., v.67, p.1456-1464, 2002.

RODRIGUES CFM, GARCIA JM. Fecundação in vitro em bovinos: aplicação comercial. Arq. Fac. Vet. UFRS; v.28, p.186-187, Supl.1, 2000.

ROMAR R, FUNAHASHI H. In vitro maturation and fertilization of porcina oocytes after a $48 \mathrm{~h}$ cultire in roscovitine, an inhibitor of $\mathrm{p} 34^{\text {cdc2 }} /$ cyclin B kinase. Animal Reproduction Science, v. 92, p. 321-333, 2006. 
ROUX, P.P.; BLENIS, J. ERK and p38 MAPK-activated protein kinases: a family of protein kinases with diverse biological functions. Microbiology and Molecular Biology, v. 68, p.320-44, 2004.

RÜSSE I. Oogenesis in cattle and sheep. Bibl Anat., v.24, p. 77-92, 1983.

SAEKI K, NAGAO Y, KISHI M, NAGAI M. Developmental capacity of bovine oocytes following inhibition of meiotic resumption by cycloheximide or 6imethylaminopurine. Theriogenology; v. 48, p. 1161-1172, 1997.

SANFINS A, PLANCHA CE, OVERSTROM EW, ALBERTINI DF. Meiotic spindle morphogenesis in vivo and in vitro matured mouse oocytes: in sights into the relationship between nuclear and cytoplasmic quality. Human Reproduction, v. 19, p. 2889-2899, 2004.

SHENG, J. et al. Dissection of c-mos degron. The EMBO Journal, v.21, p.6061-71, 2002.

SIRARD, M. A.; COENEN, K. Effects of inhibition of meiotic resumption upon the subsequent development of bovine oocytes in vitro. Journal of Reproduction and Development, v.41, p.255-62, 1994.

SIRARD MA. Resumption of meiosis: mechanism involved in meiotic progression and its relation with developmental competence. Theriogenology, v. 55, p. $1241-1254,2000$.

SUGIURA, K., NAITO, K., IWAMORI, N., KAGII, H., GOTO, S., OHASHI, S., YAMANOUCHI, K., TOJO, H. Germinal vesicle materials are not required for the activation of MAP kinase in porcine oocyte maturation. Mol. Reprod. Dev., v.59, p.215-220, 2001.

TAIEB, R.; THIBIER, C.; JESSUS, C. On cyclins, oocytes, and eggs. Molecular Reproduction and Development, v.48, p.397-411, 1997.' 
TATEMOTO, H., HORIUCHI, T. Requirement for protein synthesis during the onset of meiosis in bovine oocytes and its involvement in the autocatalytic amplification of maturatin-promoting factor. Mol. Reprod. Dev., v.41, p.47-53, 1995.

TATONE C, CARBONE MC, GALLO R, DELLE MONACHE S, DI COLA M, ALESSE E, AMICARELLI F. Age-associated changes in mouse oocytes during porstovulatory in vitro culture: possible role for meiotic kinases ans survival factor BCL2. Biology of Reproduction, v. 74, p.395-402, 2006.

THOMAS RE, THOMPSON JG, ARMSTRONG DT, GILCHRINT RB. Effect of specific phosphodiesterase isoenzyme inhibitors during in vitro maturation of bovine oocytes on meiotic and developmental capacity. Biology of Reproduction, v.71, p.1142-1149, 2004.

TIAN XC, LONERGAN P, JEONG BS, EVANS AC, YANG X. Association of MPF, MAPK, and nuclear progression dynamics during activation of young and aged bovine oocytes. Molecular Reproduction and Development. v. 62, p.132-138, 2002.

VAILLANT MF, HACCARD O, OZON R, JESSUS C. Interplay between Cdc2 Kinase and the c-Mos/MAPK Pathway between Metaphase I and Metaphase II in Xenopus Oocytes. Developmental Biology, v. 231, p.279-288, 2001

Van WEZEL IL, RODGERS RJ. Morphological characterization of bovine follicles and their environment in vivo. Biol Reprod, v. 55, p. 1003-11, 1996.

VIGNERON, C., NUTTINCK, F., PERREAU, C., REINAUD, P., CHARPIGNY, G., MERMILLOD, P. Effect of roscovitine, a cdk1 inhibitor, and of the presence of oocyte on bovine cumulus cell expansion and cyclooxygenase-2 expression. Mol. Reprod. Dev., v.65, p.114-121, 2003.

VIGNERON C, PERREAU C, DALBIÉS-TRAN, JOLY C, HUMBLOT P, UZBEKOVA S, MERMILLOD P. Protein synthesis and mRNA sotarage in cattle 
oocytes maintained under meiotic block by roscovitine inhibition of MPF activity. Molecular Reproduction and Development, v.69, p.457-465, 2004a.

VIGNERON C, PERREAU C, DUPONT J, UZBEKOVA S, PRINGENT C, MERMILLOD P. Several signaling pathways are involved in the control of cattle oocyte maturation. Molecular Reproduction and Development, v.69, p.466474, 2004b.

WESSEL, G.M., CONNER, S.D., BERG, L. Cortical granule translocation is microfilament mediated and linked to meiotic maturation in the sea urchin oocyte. Development, v. 126, p.4315-4325, 2002.

WINSTON N J. Stability of cyclin B protein during meiotic maturation and first mitotic cell division in mouse oocytes. Biology of the Cell, v. 89, p.211-219, 1997.

WU GM, SUN QY, MAO J, LAI L, PARK KW, PRATHER RS, DIDION BA, DAY BN. High developmental competence of pig oocytes after meiotic inhibition with a specific M-phase promoting factor kinase inhibitor, butyrolactone I. Biology of Reproduction, v.67, p.170-177, 2002.

WRENZYCKI, C., HERRMANN, D., hOLM, P., CALleSEN, H., NIEMANN, H. Effects of reversible inhibition of meiosis on messenger RNA expression patterns in bovine oocytes. Theriogenology. v.59, p.504, 2003.

WRENZYCKI C, HERRMANN D, NIEMANN H. Messenger RNA in oocytes and embryos in relations to embryo viability. Theriogenology, v.68, p.S77-S83, 2007.

YI, Y.J.; PARK, C.S. Parthenogenetic development of porcine oocytes treated by ethanol, cycloheximide, cytochalasin B and 6-dimethylaminopurine. Animal Reproduction Science, v. 86, p.297-304, 2005. 
APÊNDICE A

TAMPÕES PARA O ENSAIO DUPLO DE DETECÇÃO DE ATVIDADE DE MPF E MAPK 


\section{Tampão de amostra}

\begin{tabular}{lccc}
\hline Reagente & Fabricante & $\begin{array}{c}\text { Concentração } \\
\text { 2X }\end{array}$ & Concentração 1X \\
& & $0,125 \mathrm{M}$ & \\
\hline Tris-HCl 0,5 M pH 6.8 & Invitrogen & $20 \%$ & $10 \%$ \\
Glicerol & USB & $4 \%$ & $2 \%$ \\
Sódio dodecil sulfato (SDS) & Invitrogen & $10 \%$ & $5 \%$ \\
$\beta$-Mercaptoetanol & Sigma & $0,005 \%$ & $0,0025 \%$ \\
Azul de bromofenol 0,1\% & USB &
\end{tabular}

Ao utilizar o tampão em concentração 2X, diluí-lo 1:1 com água deionizada antes do uso.

A2. Tampão de coleta

\begin{tabular}{lcccc}
\hline Reagente & Faricante & $\mathbf{m M}$ & $\mathbf{~} \mathbf{g} / \mathbf{m l}$ & $\mathbf{g} / \mathbf{1 0 0 m l}$ \\
\hline EDTA & USB & 4,5 & 1,87 & 0,187 \\
$\mathrm{NaF}$ & Sigma & 10 & 0,42 & 0,042 \\
$\mathrm{Na}_{3} \mathrm{VO}_{4}$ & Sigma & 10 & 1,84 & 0,184 \\
\hline
\end{tabular}

Preparar o tampão em PBS com 0,1\% de PVA 
A3. Tampão de homogeneização

\begin{tabular}{llcc}
\hline Reagente & Fabricante & Concentração & g/10ml \\
\hline$\beta$-glicerofosfato & Sigma & $100 \mathrm{mM}$ & 0.2160 \\
p-nitrofenilfosfato & Sigma & $25 \mathrm{mM}$ & 0.0658 \\
$\mathrm{MgCl}_{2} \cdot 6 \mathrm{H}_{2} \mathrm{O}$ & USB & $25 \mathrm{mM}$ & 0.0508 \\
$\mathrm{DTT}$ & PlusOne & $1,66 \mathrm{mM}$ & 0.0026 \\
$\mathrm{Na}_{3} \mathrm{VO}_{4}$ & Sigma & $0,16 \mathrm{mM}$ & 0.0003 \\
$\mathrm{PMSF}_{\text {Leupeptina }}$ & SSB & $1,6 \mathrm{mM}$ & 0.0028 \\
Aprotinina & Migma Biomedicals & $66,6 \mu \mathrm{g} / \mathrm{ml}$ & $333 \mu \mathrm{g}$ \\
MOPS-KOH & Sigma & $41,66 \mathrm{mM}$ & $666 \mu \mathrm{g}$ \\
EGTA & Sigma & $8,33 \mathrm{mM}$ & 0.0872 \\
\hline
\end{tabular}


A4. Tampão de reação

\begin{tabular}{llcc}
\hline Reagente & Fabricante & Concentração & g/10ml \\
\hline$\beta$-glicerofosfato & Sigma & $75 \mathrm{mM}$ & 0.1620 \\
p-nitrofenilfosfato & Sigma & $18,75 \mathrm{mM}$ & 0.0493 \\
$\mathrm{MgCl}_{2} \cdot 6 \mathrm{H}_{2} \mathrm{O}$ & USB & $18,75 \mathrm{mM}$ & 0.0381 \\
$\mathrm{DTT}$ & PlusOne & $1,25 \mathrm{mM}$ & 0.0019 \\
$\mathrm{Na}_{3} \mathrm{VO}_{4}$ & Sigma & $0,1 \mathrm{mM}$ & 0.0002 \\
$\mathrm{PMSF}_{\text {Leupeptina }}$ & USB & $1,2 \mathrm{mM}$ & 0.0021 \\
Aprotinina & Sigma & $25 \mu \mathrm{g} / \mathrm{ml}$ & $250 \mu \mathrm{g}$ \\
MOPS-KOH & SP Biomedicals & $50 \mu \mathrm{g} / \mathrm{ml}$ & $500 \mu \mathrm{g}$ \\
EGTA & Sigma & $6,25 \mathrm{mM}$ & 0.0131 \\
Histona H1 & Sigma & $31,25 \mathrm{mM}$ & 0.1189 \\
MBP & Sigma & $1 \mathrm{mg} / \mathrm{ml}$ & - \\
PKA inhibitor & Sigma & $1 \mathrm{mg} / \mathrm{ml}$ & - \\
{$\left[\gamma^{-32} \mathrm{P}\right]$ ATP } & Amersham & $0,55 \mu \mathrm{M}$ & 0.0122 \\
\hline
\end{tabular}

